1 Using geoinformatics and geomorphometrics to quantify the geodiversity of

\title{
Crete, Greece.
}

${ }^{a}$ School of Earth and Environmental Sciences, University of Portsmouth, Portsmouth, PO1 3QL, $7 \mathrm{UK}$.

$8{ }^{\mathrm{b}}$ Laboratory of Geophysical - Satellite Remote Sensing \& Archaeo-environment, Institute for

9 Mediterranean Studies (I.M.S.) / Foundation of Research \& Technology (F.O.R.T.H.), 10 Melissinou \& Nikiforou Foka 130, Rethymno 74100, Greece.

$12 *$ Corresponding author: A.V. Argyriou, telephone: +302831056627, fax: +302831025810, 13 argyriou.nasos@gmail.com.

\section{Abstract}

17 geomorphometric, geological and climatic factors. A number of geomorphometric variables, extracted from the ASTER Global Digital Elevation Model (ASTER G-DEM) in conjunction

19 with geological and climatic information, are evaluated through various algorithms incorporated 20 into Geographical Information System (GIS) software's. The derived geoinformatic data sets are 
21 then analyzed to produce the geodiversity of Crete. The geodiversity map is used to quantify the

22 geodiversity, by calculating landscape diversity and other spatial pattern indices. Those indices

23 are evaluating the richness, evenness, fragmentation and shape of the landscape patch types. The

24 outcome of this study has highlighted that western Crete is characterized by complex

25 geodiversity with more irregular, elongated and fragmented landscape patterns relative to the

26 eastern part of the island. The geodiversity indices provide insights into the processes shaping

27 landscapes, particularly the "battle" between neotectonic landscape deformation and

28 erosion/deposition. The methodology presented can be useful for decision makers when

29 evaluating a regions geological heritage, planning the management of natural resources, or 30 designating areas for conservation.

32 Keywords: Geodiversity; geomorphometrics; landscape indices; geoinformatics; ASTER G-

33 DEM.

\section{Introduction}

Various physical properties of the Earth's surface are factors that influence local

37 topography, with geomorphometric landform information providing valuable knowledge

38 regarding the interfered processes shaping landscapes and producing geodiversity (Nieto, 2001;

39 Benito-Calvo et al., 2009). Gray (2004) defined geodiversity as: "The natural range (diversity) of

40 geological (rocks, minerals, fossils), geomorphological (landform processes) and soil features. It

41 includes their assemblages, relationships, properties, interpretations and systems." Kozlowksi

42 (2004), added surface waters such as lakes and rivers, as well as including the impact of human 
43 influence on geodiversity. Sharples (2002) also considered the interrelated character of the

44 assemblages, properties, systems and processes of the geological, geomorphological and soil

45 elements that produce geodiversity. The geodiversity concept has been used in various

46 applications such as geological heritage, geoconservation, ecosystem management, etc (e.g.

47 Gray, 2004, Carcavilla et al., 2008; Gordon et al., 2012; Stavi et al., 2015). The subject of

48 geodiversity has not been as widely well-established or used as a biodiversity concept. So it

49 follows that the abiotic diversity of Earth remains a relatively challenging domain to assess both

50 qualitatively and quantitatively (Pereira et al., 2013).

Although the concept of geodiversity has been widely discussed, there are relatively few

52 publications on the quantification of geodiversity (e.g. Bruschi, 2007; Serrano and Ruiz-Flano,

53 2007; Benito-Calvo et al., 2009; Ruban 2010). Pioneering work involving the classification of

54 geodiversity was carried out in the development of land systems mapping (Christian and Stewart,

55 1952; Ollier et al., 1969) and by researchers analyzing landscape parametrics (e.g. Leopold,

56 1969; Conacher and Dalrymple, 1977). However there has been a resurgence of geodiversity

57 research in recent years due to improved computing and software functionality, which via the

58 geoinformatics has provided a useful tool for managing natural resources, human resources and

59 natural hazards (e.g. Serrano and Ruiz-Flano, 2007; Parks and Mulligan, 2010; Hjort and Luoto,

60 2012; Rawat, 2013). Investigating heterogeneity in geological and geomorphological properties

61 can lead to the quantification of landscapes and towards a better understanding of their

62 complexity (Nieto, 2001; Panizza and Piacente, 2008). Physical elements such as

63 geomorphological and geological attributes, constitute the main geodiversity elements in its

64 assessment (Kozlowski, 2004; Serrano and Ruiz-Flano, 2007). A combination of geological,

65 geomorphological, climatic or hydrological information using geoinformatic approaches can be 
useful in the quantification of geodiversity for a regional scale (Benito-Calvo et al., 2009; Hjort

67 and Luoto, 2010).

This study aims to assess the geodiversity of Crete, one of the most tectonically active

69 areas in the world (Pirazzoli et al., 1996). The region is characterized by a high degree of neotectonic activity which is the main triggering agent for the development of a complex

71 heterogeneous terrain (Shaw et al., 2008). In order to assess and describe the abiotic

72 heterogeneity, this study quantifies the geodiversity of Crete, based on a regional geodiversity

73 map that includes geomorphometric, geological, hydrological and climatic information. Such

74 information can constitute the main factors in evaluating the geodiversity of a region, adopting

75 the methodology of Benito-Calvo et al. (2009), which is partly modified to fit the needs of this 76 study.

The small number of variables used by Benito-Calvo et al. (2009) to study the 78 tectonically more "quiet" region of Spain in comparison to Crete, leaves scope for more 79 geomorphometric indices to be used for a deeper investigation of the geomorphological, 80 hydrological and morphotectonic context of Crete. The final geomorphometric classification of 81 this study considers additional hydrological and morphotectonic indices that Benito-Calvo et al. 82 (2009) did not use in their study. The geomorphometric classification was based on 83 geomorphometric indices (amplitude of relief $(A r)$, stream length gradient $(S L)$, stream frequency $84(F u)$, drainage density $(D d)$, elevation relief $(E r)$, topographic wetness index $(T W I)$, slope 85 gradient $(S g)$, surface area/ratio $(S A R)$, dissection index $(D i))$; all derived from the ASTER G86 DEM, a freely-available digital elevation model with $30 \mathrm{~m}$ pixels. The geomorphometric indices 87 were spatially analyzed to provide a map of geomorphometric classes. The geological 88 classification was based on digitized 1:50,000 scale geological maps (IGME, 1971), with the 
geological classification simplifying litho-chronologically, the initial complex formations of the IGME (1971) geological maps. The climatic classification consisted of seasonal average temperature and rainfall raster data layers for the period 1930-2000, determined by the EMERIC project (Sarris, 2007; Fassoulas et al., 2007). Two different widely used approaches were tested in this study, the one by Chorley et al. (1984) for evaluating morphogenetic regions and the one of Kottek et al. (2006) providing an update of Köppen-Geiger studies for climatic zones determination (Köppen, 1936; Geiger, 1954). The results of the Chorley et al. (1984) approach did not show significant variation of morphogenetic regions, with almost the whole island being characterized as "arid" so the Kottek et al. (2006) methodology was preferred, offering a larger variance of climatic zones across Crete. Each of the aforementioned classifications, presented in detail below, were implemented using GIS softwares to obtain a regional geodiversity map of Crete, via an overlay union procedure (Benito-Calvo et al., 2009). In that way, all geodiversity components were assessed equally, avoiding overestimation of any particular components (Pereira et al., 2013).

Landscape metrics were then applied on the geodiversity map to quantify the geodiversity, following Benito-Calvo et al. (2009). This study used calculations of diversity indices which can determine the heterogeneity of landscapes, via indices such as the Patch Richness Density (PRD), Shannon's Diversity Index (SHDI), Shannon's Evenness Index (SHEI), Simpson's Diversity Index (SIDI) and Simpson's Evenness Index (SIEI). In the study of BenitoCalvo (2009), they acknowledge that the combination of the aforementioned diversity indices with other spatial pattern indices will lead to better comprehension of the landscape spatial configuration. For this reason additional spatial pattern indices, such as: i) shape index (SHAPE); ii) proximity index $(P R O X)$; iii) related circumscribing circle (CIRCLE); iv) patch density $(P D)$ 
112 and; v) perimeter-area fractal dimension (PAFRAC), were also calculated to evaluate the

113 landscape form regarding the shape and fragmentation characteristics. Those indices were

114 analyzed using Fragstats spatial pattern analysis freeware (McGarigal et al., 2002). The

115 quantification, classification and mapping of geological, geomorphological, hydrological and

116 climatic factors, can improve our understanding of the processes and materials that have

117 controlled landscape evolution across Crete. Such knowledge is new for the region offering 118 valuable information to various scientific fields for decision making, such as land use mapping, 119 geological heritage, environmental management or nature conservation.

\section{Study area}

Crete lies within the emergent outer fore-arc of the largest and most active subduction zone in Europe, the Hellenic arc and is therefore characterized by high rates of tectonic activity 124 and seismicity (Papazachos and Comninakis, 1978; Kelletat, 1996; Pirazzoli, 2005) (Fig. 1). By 125 way of an example, the 21 July AD 365 earthquake (Mw 8.3-8.5), the "Early Byzantine 126 Tectonic Paroxysm", produced co-seismic uplift up to 9 meters on southwestern Crete 127 (Pirazzoli et al., 1996; Stiros, 2001; Shaw et.al, 2008). The island is characterized by low to 128 medium elevation (up to $\sim 900 \mathrm{~m}$ ) on its northern coast and high elevation (up to $\sim 2500 \mathrm{~m}$ ) with 129 steep slopes on the southern coast, with N-S trending deeply incised valleys (Fytrolakis, 1980; 130 Sarris, 2005). Two large massifs, the Lefka Ori and Psiloritis mountains, are found in the western 131 and central part of the island, with peaks of up to $2500 \mathrm{~m}$ (Fig. 1: labeled as LO and P 132 respectively). The geological and tectonic setting of the island was initially investigated in 133 the early 1950s (Papastamatiou \& Reichel, 1956; Papastamatiou et al., 1959). These studies 134 indicated the presence of two major nappes, the Pindos nappe overlying the Tripolis nappe 
135 unit. These units belong to the external Hellenides and were deformed after the deposition of 136 flysch formations in the Late Eocene-Oligocene (Renz, 1955; Aubouin and Dercourt, 1970).

137 Further work in the 1970s established a better tectonostratigraphic framework for Crete by 138 indicating the presence of several nappes, either below the Tripolis unit or above the Pindos 139 nappe (Seidel, 1971; Baumann et al., 1976). The geological setting of the island of Crete is very 140 complex and it is characterized by pre-Alpine and Alpine rocks (composing a pile of nappes) and 141 post-Alpine rocks (Neogene and Quaternary sediments) (Fig. 2). In the case of pre-Alpine and 142 Alpine rocks, the Cretan nappe pile consists of two nappe groups: i) the upper nappes (Tripolis, 143 Pindos, Uppermost) and; ii) the lower nappes (Plattenkalk, Trypali, Phyllite/Quartzite). In the 144 post-Alpine rocks, the sediments of Crete can be divided into six groups: i) Prina group, ii) Tefeli 145 group, iii) Vrysses group, iv) Hellenikon group, v) Finikia group, and vi) Agia Galini group 146 (Meulenkamp et al., 1979).

\section{Methods and Datasets}

\subsection{Regional Geodiversity}

In order to determine geomorphometric classification, several geomorphometric variables extracted from the ASTER G-DEM were evaluated (Fig. 3). In a similar study, Benito-Calvo et

154 perform a geomorphometric classification. In order to highlight additional geomorphological, 155 hydrological and morphotectonic information for this tectonically active region, various other variables were analyzed in this study. The geomorphological information was mainly derived by 
157 indices, such as $S A R, S g, E r$ and $D i$, highlighting the terrain roughness, dissection, concavity or 158 convexity (Singh and Dubey, 1994; Jenness, 2004; Rowberry, 2012) (Fig. 4). The 159 morphotectonic information was contributed prior by indices such as $A r$, SL (Ciccacci et al., 160 1988; Toudeshki and Arian, 2011) (Fig. 4). Some supplementary indices such as $D d, F u$ and $T W I$ 161 were acknowledged to provide hydrological information while their interrelation can also 162 highlight both geomorphological and morphotectonic information (Kouli et al., 2007; Argyriou 163 et al., 2016) (Fig. 4). The indices to be used in the geomorphometric classification were derived 164 after prior evaluation of the low interdependency of various DEM derivatives by selecting the 165 non-correlated ones (Table 1). The following geomorphometric indices and their contributed 166 geomorphological, hydrological and morphotectonic information were considered:

170 can also be used to determine fluvial erosion (Della Seta et al, 2004). Following the method of 171 Della Seta et al. (2004), the relative relief was determined by subtraction of the ASTER G$172 \mathrm{DEM}_{\max }$ (each output cell contains the maximum of the input cells that are encompassed by the

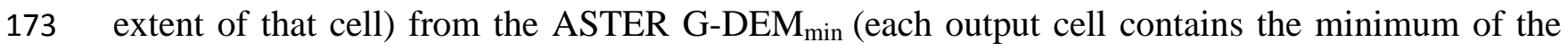
174 input cells that are encompassed by the extent of that cell), within a grid of $1 \times 1 \mathrm{~km}$ cells 175 (Argyriou et al., 2016). The $A r$ values were determined by the centroid points of each unit area, 176 while kriging was used as the interpolation method, to produce a spatial distribution map of $A r$ 177 (Troiani and Della Seta, 2008). The higher values of the $A r$ index imply to vertical displacements 178 of uplifted or subsidence blocks, while regions with no intense landscape deformation are 179 highlighted by their low values (Ciccacci et al., 1988; Argyriou et al., 2016). 
181

182

183

184

185

186

187

188

189

190

191

192

193

194

195

196

197

198

199

200

201

202 length of that reach, multiplied by the total length of the channel from the point where the index is being calculated (Hack, 1973; Keller, 1986; Toudeshki and Arian, 2011) (Fig. 4). Tectonic activity and rock resistance to erosion are the main factors that can be investigated using the $S L$ index (Keller and Pinter, 1996; Garcia-Tortosa et.al, 2008). Any abrupt changes in the gradient of river will be revealed by the high values of the $S L$ index and can be linked to active tectonics, while lower index values imply a fine drainage network without any influence of landscape deformation (Garcia-Tortosa et.al, 2008). The stream network was delineated from the ASTER G-DEM, by filling the voids using the D8 algorithm and the ArcGIS hydrology module to extract drainage network. A flow accumulation threshold value of $400 \mathrm{~m}^{2}$ provided the best fit for drainage network delineation, based on examination of satellite images, aerial photographs and topographical maps to determine vegetation corridors along floodplains (Tarboton et al., 1988; Maidment, 2002; Li, 2014; Argyriou et al., 2016).

Stream frequency $(\boldsymbol{F u})$ evaluates the total number of the stream segments to the area of the basin (Horton, 1945) (Fig. 4). The values of $F u$ indicate the degree of slope steepness, rock permeability and surface runoff. High $F u$ values $(>5)$ are associated with impermeable surface material, high relief and low infiltration capacity, while low $F u$ values imply permeable surface material, low relief and high infiltration capacity (Reddy et al., 2004; Ozdemir and Bird, 2009; Bagyaraj and Gurugnanam, 2011). The high $F u$ values can be indicative for areas with coarse drainage network and with the distortion of the drainage system being a result of neotectonic forces (Kouli et al., 2007). This index was calculated within a GIS software package by using kernel density within a search area of $2 \mathrm{~km}$ for the derived drainage network (Zavoianu, 1985; Kouli et al., 2007). 
Drainage density $(\boldsymbol{D d})$ determines the total stream length, relative to the area of the basin 204 (Horton, 1945) (Fig. 4). Dd provides information about surface runoff potential, the degree of 205 landscape dissection, rock permeability and resistance to erosion can be assessed (Verstappen, 206 1983; Tucker and Bras, 1998; Mesa, 2006). Dd is controlled by factors such as slope gradient 207 and relative relief: low values (ie, < 5) are associated with a coarse drainage network, low relief, 208 permeable surface material and terrain with long hill slopes (Berger and Entekhabi, 2001; 209 Sreedevi, 2009). High $D d$ values indicate fine drainage texture, high relief, impermeable surface material and a dissected terrain (Strahler, 1964; Awasthi et al., 2002).

Elevation relief $(\boldsymbol{E r})$ describes rugosity in a continuous raster surface and provides 212 hypsometric information about a watershed (Pike and Wilson, 1971) (Fig. 4). It is equivalent to 213 the hypsometric integral and can indicate the degree of disequilibrium in the balance of erosive 214 and tectonic forces (Strahler, 1952, 1958; Luo, 1998; Keller and Pinter, 2002). The Er indicates 215 the degree of landscape dissection (Clarke, 1966; Evans, 1972). Using Er, it is possible to 216 discriminate lowland plains and dissected upland plateaus in a manner that cannot be achieved 217 using slope angle or relative relief. A value near to 0 is indicative of concavity or sub-horizontal 218 terrain with some isolated peaks, whereas a value near to 1 is indicative of convexity or sub219 horizontal terrain with deep incision (Rowberry, 2012).

The Topographic Wetness Index (TWI) evaluates the soil moisture and surface saturation 221 that is influenced by the changes in slope position such as shedding slopes or receiving slopes 222 (Beven and Kirkby, 1979; Sorensen, 2005) (Fig. 4). The accumulation of water at the foot of 223 slopes leads to a straight dependent relation with this index. It can also identify regions with low 224 values indicating: i) V-shaped valleys characterized by high incision; ii) high relief surfaces 225 where moisture accumulation exists in lower degree and; iii) longitudinal ridges. The higher 
226 values of the index can assess regions consisting of: i) low gradient surface and moisture 227 accumulation at higher degree, or ii) alluvial deposits (Migon et al., 2013). The TWI can be 228 useful in evaluating land surface water distribution due to topographic changes and landscape 229 deformation (Anderson and Kneale, 1982; Hjerdt et al., 2004; Argyriou et al., 2016).

Slope gradient $(\mathbf{S g})$ shows the change occurring in elevation between each cell and its neighbors (ESRI, 2003) (Fig. 4). Flat surfaces are characterized by low values while a steep 232 relief is indicated by the higher values.

The surface area/ratio (SAR) generates a surface area and surface ratio raster layer from 234 the ASTER G-DEM data (Fig. 4). The cell values for the new raster reflect the surface area and 235 the surface ratio (surface area / planimetric area) for the land area contained within that cell's 236 boundaries (Jenness, 2004). They provide useful indices of topographic roughness and 237 convolutedness, giving a more realistic estimate of the land area available in relation to the 238 simple planimetric area (Berry, 2002; Jenness, 2004). Surface area grids may easily be 239 standardized into $S A R$ grids by dividing the surface area value for each cell by the planimetric 240 area within that cell. High values of $S A R$ will indicate a rough and dissected terrain while lower 241 index values will highlight smoother ones of low roughness (McAdoo et al., 2004).

The Dissection index $(\mathrm{Di})$ is the ratio between absolute relief and relative relief, 243 indicating the degree of dissection or vertical erosion (Singh and Dubey, 1994) (Fig. 4). It is a 244 useful index for the study of terrain dynamics and landscape evolution, particularly the 245 interaction between erosion and deposition (Mukhopadhyay, 1984; Sen, 1993). Low values of $D i$ 246 indicate lack of vertical dissection/erosion and hence dominance of flat surface, while high $D i$ 247 values suggest highly dissected terrain with vertical escarpment of hill slope (Pareta et al., 2011). 
Many researchers have shown that the aforementioned indices are effective indicators of

249 the Earth's surface processes driving landscape evolution (e.g. Currado and Fredi, 2000;

250 Jamieson et al., 2004; Toudeshki and Arian, 2011). A correlation coefficient matrix has been

251 produced to validate the low interdependency of the nine selected variables (Table 1). The

252 correlation coefficient matrix showed that the indices were characterized by low correlation to

253 each other (values <0.6). Consequently, selected indices can provide a range of variant

254 information regarding the geomorphological, hydrological and morphotectonic context to the

255 final geomorphometric classification.

The next step of the analysis was to carry out a geomorphometric classification of the

257 nine variables using the Interactive Self-Organizing Data Analysis Technique (ISODATA)

258 algorithm. In this stage, clustering of the multivariate data takes place using an initial clustering

259 with a large number of classes, in order to determine the characteristics of the natural grouping

260 of cells (Benito-Calvo et al., 2009). A clustering histogram analysis, with an initial cluster of 90

261 classes, was selected for the nine variables (Fig. 5B). The number of classes was ten times larger

262 than the nine variables being used herein, following Benito-Calvo et al. (2009), where 40 classes

263 were considered for the four selected variables. The clustering histogram curve approach

264 highlighted eight major geomorphometric classes, separated by natural breaks, as prior terrain

265 units (Fig. 5B). The eight classes of the geomorphometric classification, provided a more

266 detailed overview of the geomorphological, hydrological and morphotectonic properties, relative

267 to the study of Benito-Calvo et al. (2009), where only geomorphological characteristics were 268 acknowledged (Table 2, Fig. 5 A and C).

$269 \quad$ ii) Climatic classification 
271 (1950-2000) and rainfall (1930-2000), as raster data layers (Soupios et al., 2005; Sarris et al.,

272 2006). The climatic classification was based on the update Koppen-Geiger approach suggested

273 by Kottek et al., (2006), using monthly temperature averages and monthly precipitation totals, as

274 raster data layers (Köppen, 1936; Geiger, 1954) (Fig. 3). Kottek et al. (2006) identified five main

275 global climatic types: group $A$, tropical/megathermal; group $B$, dry (arid and semiarid); group $C$,

276 temperate/mesothermal; group $D$, continental/microthermal and; group E, polar and alpine,

277 (Table 3). According to specific precipitation/temperature criteria, each group consists of various

278 subcategories. Group $C$ is the one that characterizes Crete, with subgroups varying across the 279 island (Fig. 6).

iii) Geological classification

The geological map from IGME (1971), consisting of 74 rock formations from different 282 geological zones, was used in the geological classification (Fig. 3). These formations were 283 simplified to 12 main geological units, based on their rock types (sedimentary, metamorphic, 284 volcanic) and their age (Cenozoic, Mesozoic and Paleozoic), as determined by the EMERIC 285 project (Sarris, 2007; Fassoulas et al., 2007) (Fig. 7 and Table 4). The dominant formations in 286 Crete are sedimentary and metamorphic rocks of Cenozoic and Mesozoic age, with only the 287 Plattenkalk nappe being of Paleozoic age (Table 4). For each of the twelve geological units, the 288 areal extent of the overlying geomorphometric classes was calculated (Table 4).

The spatial datasets were combined using an overlay union procedure, producing a 291 regional geodiversity map of 229 discrete classes (Benito-Calvo et al., 2009) (Fig. 8A). 
292 Comparison of the occurrences, for the three spatial datasets used in the geodiversity map, 293 highlights the distribution of the dominant geomorphometric, geological and climatic classes 294 across Crete (Fig. 8B).

The geometric and spatial composition of landscapes can be evaluated to quantify the 297 geodiversity of Crete. One of the operations is diversity, a landscape property, consisting of 298 richness and evenness (Spellerberg and Fedor, 2003). The number of classes can be defined by 299 the compositional component of diversity, richness; while the distribution of the area of different 300 classes can be quantified via the evenness of the diversity. Specific parameters were calculated in 301 order to assess the geodiversity (Fig. 3 and Table 5). The quantification of landscape 302 heterogeneity across Crete was achieved by evaluating various diversity and spatial pattern 303 indices, using the Fragstats pattern analysis freeware (McGarigal et al., 2002). The examined 304 indices were: Patch Richness Density (PRD), Shannon's Diversity Index (SHDI), Simpson's 305 Diversity Index (SIDI), Simpson's Evenness Index (SIEI) and Shannon's Evenness Index (SHEI) 306 (Table 5). Some indices (e.g. SHDI) are more sensitive to richness than evenness (Shannon and 307 Weaver, 1949). As a result, rare patch classes disproportionately influence the weighting of the 308 index. For instance, SIDI is less sensitive to richness and as a result it disproportionately 309 influences the weight of the common patch classes (Simpson, 1949). Large areas can have an 310 increased richness, due to greater heterogeneity in comparison to smaller areas.

312 for a given patch richness: it is used to determine the distribution of area among patch classes. As 313 evenness approaches 1, the observed diversity reaches perfect evenness; conversely, larger 
314 values imply greater landscape diversity. The set of quantitative indices were evaluated for each

315 district of Crete, regarding the geodiversity map and each factor individually (Table 6).

These diversity indices when combined with other spatial pattern indices can improve the

317 understanding of the landscape spatial composition (Benito-Calvo et al., 2009). As Crete is

318 characterized by a complex neotectonic status and a high degree of heterogeneity, extra spatial

319 pattern indices were considered in this study to examine the complex landscape spatial 320 composition and to quantify its shape and fragmentation characteristics. Those extra indices 321 were: i) shape index (SHAPE); ii) proximity index (PROX); iii) related circumscribing circle 322 (CIRCLE); iv) patch density (PD) and; v) perimeter-area fractal dimension (PAFRAC) (Table 5 323 and 6). Such characteristics can be associated with the degree of neotectonic activity influencing 324 an area, by highlighting any irregular, elongated and highly fragmented landscapes.

\section{Results}

The geomorphometric classification was based on the nine thematic maps presented in 328 Fig. 4. These maps were combined to derive eight geomorphometric classes (Fig. 5 and Table 2). 329 The following observations were made for the geomorphometric classification, relative to the 330 geological formations (Table 4 and Fig. 8B):

$331 \quad$ More than half of the Quaternary (Q.al) coverage ( 11\% total area coverage) is found over coastal lands and plains (mean height: $108 \mathrm{~m}$ ) with gentle slopes (mean: $7.8^{0}$ ), low roughness, minimal dissection and minimal landscape deformation. 

valleys with low relief, up to a mean height $371 \mathrm{~m}$ asl, with low roughness, minimal dissection and minimal landscape deformation.

- $\quad$ The Tripolis Flysch zone $(f t)$ is characterized by geomorphometric classes 2, 3 and 4, occurring at mean heights of $371 \mathrm{~m}$ asl, with variable dissection and roughness.

- $\quad$ The Pindos Flysch zone $(f o)$ is characterized by similar geomorphometric classes to the Tripolis Flysch zone $(f t)$ with a higher percentage found over steep hillsides and valley slopes (mean slope: $21^{0}$ ) at a mean height of $493 \mathrm{~m}$ asl, associated with high roughness and severe landscape deformation.

- $\quad$ The Flysch-Schist allochthonous rocks $(f)$ are rare, with their distribution characterized by geomorphometric classes 2, 3 and 4 .

- $\quad$ The Ophiolites (o) have a small areal extent, mainly occurring between 493-617 m asl, characterized by the geomorphometric classes 4 and 5, with a large percentage found in plateaus and plains.

The Carbonate allochthonous rocks $(K . m)$ have small areal extent, mostly over low relief plains and valleys with minimal dissection.

The Carbonate Pindos rocks $(K-E)$ have a small areal extent ( $\sim 3 \%$ total area coverage) and are found mainly in Rethymno and Herakleio districts. This tectonic nappe formation is characterized by the geomorphometric classes 3, 4 and 6, occurring between 371-838 $\mathrm{m}$ asl, on gentle to steep slopes (mean: $10^{0}-22^{0}$ ), characterized by a very high degree of landscape deformation and high roughness.

The Carbonate Tripolis rocks $(K . k)(\sim 15 \%$ total area coverage) are distributed over most of the geomorphometric classes (classes 2 to 7$)$; the highest percentage ( $22 \%)$ is found 
at a mean height of $493 \mathrm{~m}$ asl with steep relief (mean: $22^{0}$ ). This tectonic nappe formation is characterized by a high degree of landscape deformation and roughness. intermediate relief (mean: 208-838 $\mathrm{m}$ asl) and by geomorphometric classes 4 and 2; moderate to steep slopes (mean: $17^{0}-21^{0}$ ) and moderate to high roughness of hillsides and valley slopes.

The Carbonate Tripali rocks $(T . b r)$ have a small areal extent $(\sim 3.6 \%$ total area coverage), mainly at high elevation (mean height: $838-1188 \mathrm{~m}$ asl) in geomoprhometric classes 7 and 6. It is characterized by steep slopes (mean: $20^{0}-22^{0}$ ), with a high degree of landscape deformation, dissection and roughness.

367 - The Plattenkalk nappe $(J-E)(\sim 16 \%$ total area coverage $)$ is distributed over intermediate to high relief areas (mean: 493-1745 m asl), characterized by geomorphometric classes 4,

6, 7 and 8 . The Plattenkalk unit is characterized by steep slopes (mean: $21^{0}-24^{0}$ ), very high dissection, high roughness and V-shaped valleys associated with severe landscape deformation.

372

Crete corresponds to group $C$ of the updated Koppen-Geiger climate classification: warm 374 temperate climate (sub-classes Cas, Cbs, Caf and Cbf) (Table 3). Cas type (hot and dry summer) 375 is the dominant climate type (Fig. 6). Cas is distributed over all the geomorphometric classes, 376 with a high percentage characterized by low to intermediate relief, where $Q . a l, M k$ and $K . k$ 377 formations exist, while the percentage of this climatic type decreases above $\sim 800 \mathrm{~m}$ asl (Fig. 378 8B). The Caf type (hot summer without dry season) is distributed over all the geomorphometric 379 classes, but mainly characterizes the high relief mountainous blocks of Lefka Ori and Psiloritis 
380

381

382

383

384

385

386

387

388

389

390

391

392

393

394

395

396

397

398

399

400

401

402

(Fig. 1). The Cbs type is found at mid to high altitudes (371-1188m asl) (Fig. 6), because of its climatic limits: the temperature of the hottest month is less than $22^{0} \mathrm{C}$, but for 10 months per year the temperature remains more than $4^{0} \mathrm{C}$ (Fig. 8B).

Although the regional climatic classification approach of Kottek et al (2006) shows more details than the widely used Köppen-Geiger approach, its 0.5 degree $(\sim 50 \mathrm{x} 50 \mathrm{~km})$ spatial resolution still only characterizes the whole of Crete as having a Cas climate type. In this study a more detailed spatial resolution $(0.6 \times 0.6 \mathrm{~km})$ of temperature and rainfall datasets was used, as determined by the EMERIC project (Sarris, 2007; Fassoulas et al., 2007). This produced a more detailed climatic classification of Crete which: revealed a wider range of climatic variation, with four climatic zones (Cas, Cbs, Caf, $C b f$ ).

Based on the quantification of the geodiversity map, the highest $P R D$ values were observed for Rethymno ( 0.1) and Herakleio ( 0.07) districts (Table 6), which have rock outcrops of relatively small areal extent and contain all the 12 geological formations. Large-area geological formations dominate Chania and Lasithi districts, which have the lowest $P R D$ values ( $\sim 0.04$ and $\sim 0.05$ respectively) and contain 10 of the 12 geological formations (Table 6). Such observations are in accordance with the findings of Benito-Calvo et al. (2009), where an inverse correlation between $P R D$ values and geological areas were observed. It indicates that $P R D$ is not an appropriate index for the comparison of landscapes with variable areal extents, nor for evaluation of richness in complex, multi-lithology geological settings (Benito-Calvo et al., 2009).

The geodiversity of Crete was evaluated as $S H D I=4.32$ or $S I D I=0.976$ (Table 6). For the individual districts, SHDI varies from 3.72 to 4.16 and the SIDI varies from 0.951 to 0.975 (Table 6). Crete is characterized by very high diversity values, indicating the tectonically active 
403 status in the region. It also has the highest SHDI and SIDI values in the geological classes (Table 404 6), indicating high diversity and heterogeneous landscapes, due to the complex geological 405 context across the island. Regarding the individual districts, the SHDI values are highest for 406 Rethymno ( 4.16), with Lasithi ( 3.72) having the lowest value. The SIDI values are also the 407 highest for Rethymno region, indicating the high diversity status, with the presence of all 12 408 geological formations. That high diversity can be linked to the active Spili fault, a normal fault 409 that extends onshore for $\sim 20 \mathrm{~km}$ and traverses the central part of Crete with a NW-SE strike 410 (Mouslopoulou, 2011). The Herakleio district has the lowest diversity values in 411 geomorphometric classes (Table 6), with low relief alluvial deposits and gentle slopes. In 412 general, western Crete (Chania and Rethymno districts) has higher diversity values in the 413 geomorphometric classes than eastern Crete (Herakleio and Lasithi districts), reflecting the 414 higher diversity and heterogeneity of the west, which experiences most of Crete's neotectonic 415 activity, such as uplift and fault movement (Stiros, 1996; Shaw et al., 2008). The dominant 416 geomorphometric classes that characterize western Crete indicate deep incised valleys, steep 417 slopes, dissected terrain and high roughness, contrasting with the low relief alluvial deposits, 418 gentle slopes, plains and low roughness of eastern Crete (Fig. 5 and Table 2).

419 Herakleio district has the lowest SHEI and SIEI values, indicating its low 420 geomorphometric heterogeneity (Table 6). Lasithi has higher values of SHEI than Herakleio for 421 the geodiversity map and geomorphometric classification, but the lowest SHEI values for the 422 geological classification (Table 6). For the geological classification, Lasithi has a landscape 423 where the distribution of area among the different geological formations becomes increasingly 424 uneven, with $J-E, K . k$ and $M k$ formations dominating. Rethymno district has the highest 425 evenness indices values, with similar proportional relations as the respective diversity values. 
Western Crete is characterized by maximum evenness, relative to eastern Crete, with the

427 variation among the evenness indices being quite discrete (Table 6). Such variation could be

428 linked to the extensive area of low relief plains that characterize eastern Crete, relative to the

429 more complex heterogeneous terrain of western Crete, with its higher degree of neotectonic 430 activity.

To quantify the landscape shape characteristics, the spatial pattern indices of SHAPE,

432 CIRCLE and PAFRAC were calculated (Table 6). High values for SHAPE were found in

433 Rethymno district where the patch shape becomes more irregular, due to dissected terrain with

434 V-shaped incised valleys and steep slopes, indicating severe landscape deformation. Lower

435 SHAPE values are observed in Lasithi district, where more regular patches correspond to lower

436 landscape deformation and extensive low relief plains (Table 6). CIRCLE values are higher for

437 Chania and Rethymno, with elongated landscape patches where elongation can be associated

438 with active tectonics. High values of PAFRAC occur on the geological classes observed in

439 western Crete, indicating the complex geodiversity of the region, with highly convoluted 440 perimeters relative to the lower values that characterize Herakleio and Lasithi (Table 6). In the 441 geodiversity map there are a few small variations with simple shape perimeters, highlighted by 442 the lowest values of the index in Herakleio district (Table 6). In the geomorphometric 443 classification, the smallest patch shape complexity is observed in Lasithi district, with higher 444 complexity in Herakleio linked to the diverse transition from low relief plains to high relief steep 445 mountain blocks (e.g. Psiloritis) and the southern coastline, where active faults in the Messara 446 basin form rough terrain (Mouslopoulou, 2011) (Table 6). 
geodiversity map, indicating the complex geodiversity for western Crete. Lasithi district has very high $P D$ values for the geological classification, which indicates a diverse geological pattern with the presence of all 12 geological formations. Herakleio district has the highest $P D$ values regarding the geomorphometric classes, but the lowest for the terrain and geological classifications (Table 6). In this case, Herakleio district has uniform terrain and landscape patterns, from large areas of low relief plains on Cenozoic formations, contrasting with its southern coast, where most of the geomorphological classes are present in rough terrain with active faults (Mouslopoulou, 2011). Low PROX values for all classifications characterize Rethymno district, indicating high fragmentation (Table 6). Herakleio district has the highest PROX values, indicating homogenous patches which are less fragmented in distribution.

\section{Discussion}

This study has assessed the geodiversity of Crete by quantifying its terrain characteristics, based on geomorphological, geological and climatic information. The methodology followed the approach of Benito-Calvo et al. (2009), with a few modifications, notably:

i) the geomorphological classification consisted of various geomorphometric indices to highlight the geomorphological, hydrological and morphotectonic context;

ii) the climatic classification was based on the Kottek et al (2006) approach, but used a higher-resolution grid $(0.6 \times 0.6 \mathrm{~km})$ which revealed a larger variation of climatic zones;

iii) the geodiversity quantification was based on a higher number of spatial pattern indices: as well as landscape evenness and diversity, we also examined fragmentation, shapes and their linkages.

The distribution of nappes across Crete is well recorded (e.g. Seidel et al., 1982; Fassoulas et al., 1994) but their geomorphological characteristics are less well known. The 
472 geomorphometric classification derived in this study determined the geomorphological context

473 of those geological units. Based on the topographic, permeability and rock strength

474 characteristics of the geological units, the nappes were characterized in terms of their roughness,

475 dissection, landscape deformation, rock resistance to erosion and steepness. The erosion-

476 resistant nappes (J-E, T-Br $P h-T, K . k$ and $K-E$ formations) form high relief regions,

477 characterized by moderate to high roughness and dissection with V-shaped valleys, low moisture

478 accumulation (lack of fine drainage network) and interlinkage with tectonic activity. The post-

479 Alpine rocks, such as the weak $Q . a l$ and $M k$ formations, are found in low relief regions with less

480 dissected plains and valleys, characterized by high moisture accumulation, fine drainage texture

481 and smooth-relief landscapes that are devoid of features that indicate abrupt/tectonic

482 deformation, such as fault scarps.

The Benito-Calvo et al. (2009) study quantified geodiversity based on diversity and 484 evenness determinations. In this study, additional spatial pattern indices were considered for 485 quantifying geodiversity. This has produced a better understanding of the fragmentation and 486 shape characteristics of landscape patterns across Crete, by evaluating the degree of homogeneity 487 or heterogeneity, the distributed fragmentation (or irregularity) of the landscape and link to 488 neotectonic activity.

The methodology presented in this study can be useful for decision makers when evaluating a region's geological heritage, planning the management of natural resources or 491 designating areas for conservation, for instance. Crete is a 'natural laboratory' with a rich 492 geological heritage and diverse terrain. It has a dynamic landscape with high neotectonic activity 493 interacting with weathering and erosion to shape its terrain and landscape structure. In the 494 context of climate change, population pressure/urbanization and degradation of natural resources, 
495 the quantification of geodiversity - facilitated by geoinformatics - provides valuable data and 496 maps for planners, decision-makers and policy-makers (Kostrzewski, 2011).

\section{Conclusions}

During the last decade the assessment of geodiversity has become a major research topic

500 of the geoinformatic research community with landscape indices providing a powerful approach.

501 The evaluation of geomorphometric, geological and climatic data sets can be integrated using

502 low-cost GIS techniques, highlighting information within the interlinked geographic data. Such

503 data integration, analysis and mapping can produce a geodiversity map which can highlight and

504 categorize the characteristic information. The geodiversity map, along with landscape richness,

505 evenness, fragmentation and shape irregularity, were examined via the calculated landscape

506 indices. Those indices highlighted the correlations between the areal extent of lithologies for

507 each district across Crete, with larger lithological units dominating Chania and Lasithi districts.

508 The outcome showed that Rethymno district is characterized by maximum richness and

509 evenness, while high diversity and heterogeneous landscapes characterized Chania district.

510 Western Crete is characterized by complex geodiversity with a more irregular, elongated and

511 fragmented landscape pattern, relative to the eastern part of the island. The overall extracted

512 data, gives important information for quantifying geodiversity across Crete. The methodology

513 presented provides useful information for research into landscape composition and specific

514 geodiversity concerns, such as the aesthetic value of one landscape type over another. This can

515 be especially useful when delineating the boundaries of national parks and other protected areas. 
The work was supported by the project POLITEIA of Action KRIPIS of the General Secretary for Research and Technology under the framework of the operational programme “Competitiveness and Entrepreneurship - NSRF 2017-2013”.

Anderson, M. G. and Kneale, P. E. (1982): The influence of low-angled topography on hillslope soilwater convergence and stream discharge. Journal Hydrol., 57, pp $65-80$.

Argyriou, A.V., Teeuw, R.M., Rust, D., Sarris, A., 2016. GIS multi-criteria decision analysis for assessment and mapping of neotectonic landscape deformation: A case study from Crete. Geomorphology. Vol. 253, pp. 262-274.

Aubouin, J. and Dercourt, J., 1970. Sur la geologie de 1' Egee: regard sur le Dodecanese meridional (Kassos, Karpathos, Rhodes). Bull. Soc. Géol. France 7, XII, pp. 455-472.

Awasthi, K. D., Sitaula, B. K., Singh, R. B. R., Bajacharaya, M., 2002. Land-use change in two Nepalese watersheds: GIS and geomorphometric analysis. Land Degrad. Develop. 13, pp 495-513.

Bagyaraj, M. and Gurugnanam, B., 2011. Significance of Morphometry Studies, Soil Characteristics, Erosion Phenomena and Landform Processes Using Remote Sensing and GIS for Kodaikanal Hills, A Global Biodiversity Hotpot in Western Ghats, Dindigul District, Tamil Nadu, South India. Research Journal of Environmental and Earth Sciences 3(3), pp 221-233.

Baumann,A., Best, G., Gwosdz, W., Wachendorf, H., 1976. The nappe pile of eastern Crete. Tectonophysics, 30, pp. 33-40.

Benito-Calvo, A., Perez-Gonzalez, A., Magri, O., Mesa, P., 2009. Assessing regional geodiversity: the Iberian Peninsula. Earth Surf. Process. Landforms 34, pp 1433-1445.

Berger, K. and Entekhabi, D.: Basin Hydrologic Response Relations to Distributed Physiographic Descriptors and Climate, J. Hydrol., 247, pp 169-182.

Berry, J. K., 2002. Use surface area for realistic calculations. Geoworld 15(9), pp 20-21.

Beven, K.J and Kirkby, M.J (1979): A physically baased, variable contributing area model of basin hydrology. Hydrol. Sci.Bull., 24, pp 43-69.

Bruschi, VM. 2007. Desarrollo de una metodología para la caracterización, evaluación y gestión de los recursos de la geodiversidad, PhD Thesis, Universidad de Cantabria, Santander; pp 355.

Carcavilla L., Duran J.J., Lopez-Martınez J., 2008. Geodiversidad: concepto y relacion con el patrimonio geologico. Geo-Temas 10, pp. 1299-1303 (in spanish with english abstract). 
Chatzaras, V., Xypolias, P., and Doutsos, T., 2006. Exhumation of high pressure rocks under continuous compression: a working hypothesis for southern Hellenides (central Crete, Greece). Geological Magazine, v. 143 , no. 6 , pp. $859-876$.

Chorley, R.J., Schumm, S.A., Sugden, D.E., 1984. Geomorphology. Methuen \& Co: London; pp. 605.

Christian, C.S., and Stewart, G.A., 1952. Summary of general report on survey of Katherine-Darwin Region, 1946. Land Research Series, 1, CSIRO, Australia, pp 24.

Ciccacci, S., De Rita, D., Fredi, P., 1988. Geomorfologia quantitativa e morfotettonica dell'area di Morlupo-Castelnuovo di Porto nei Monti Sabatini (Lazio). Supplemento di Geografia Fisica e Dinamica Quaternaria I, pp 197-206.

Ciotoli, G., Della Seta, M., Del Monte, M., Fredi, P., Lombardi, S., Lupia Palmieri, E., Pugliese, F., 2003. Morphological and geochemical evidence of neotectonics in the volcanic area of Monti Vulsini (Latium,Italy). Quaternary International 101-102, pp 103-113.

Clarke, J.I. 1966. Morphometry from maps. In: Dury, G.H. (ed) Essays in Geomorphology. London, Heinemann, pp 235- 274.

Conacher, A.J. and Dalrymple, J.B., 1977. The Nine-unit Landsurface Model: an approach to pedogeomorphic research. Geoderma, 18, pp 1-154.

Currado, C. and Fredi, P. (2000): Morphometric parameters of drainage basins and morphotectonic setting of eastern Abruzzo. Memorie della Società Geologica Italiana, 55, pp 411-419.

Della Seta, M., Del Monte, M., Fredi, P., Lupia Palmieri, E., 2004. Quantitative morphotectonic analysis as a tool for detecting deformation patterns in soft-rock terrains: a case study from the southern Marches, Italy. Géomorphologie: relief, processus, environnement, n 4, pp 267-284.

ESRI, 2003. ArcGis Desktop Help, in ArcMap utility.

Evans, I.S. 1972. General geomorphometry, derivatives of altitude, and descriptive statistics. In: Chorley, R.J. (ed) Spatial Analysis in Geomorphology. London, Methuen, pp 17-90.

Fassoulas, C., Kilias, A. and Mountrakis, D., 1994. Postnappe stacking extension and exhumation of high-pressure/low temperature rocks in the island of Crete, Greece. Tectonics,13, pp. 127-138.

Fassoulas, Ch., Georgila, K., Sarris, A., Kokkinaki, M., 2007. Geohazard risk assessment based on the evaluation of Cretan faults, Crete-Greece. The 6th International Symposium on Eastern Mediterranean Geology \& The 9th International Conference of Jordanian Geologists Association, Amman, Jordan.

Fytrolakis, N., 1980. The geological structure of Crete: Problems, observations, and conclusions. Habil. Thesis, Nat. Techn. Univ. Athens, pp.143.

García-Tortosa, F.J., Alfaro, P., Galindo-Zaldívar, J., Gibert, L., López-Garrido, A.C., Sanz de Galdeano, C., Ureña, M., 2008. Geomorphologic evidence of the active Baza Fault (Betic Cordillera, South Spain). Geomorphology 97, pp 374-391.

Geiger, R., 1954. Klassifikationen der Klimate nach W. Köppen. In:Landolf-Börnstein:Zahlenwerte und Funktionen aus Physik, Chemie, Astronomie, Geophysik und Technik, (alte Serie), Vol. 3. Springer, Berlin, pp 603-607. 
Gordon, J.E., Barron, H.F., Hansom, J.D., Thomas, M.F., 2012. Engaging with geodiversity-why it matters. Proc Geol Assoc, 123, pp. 1-6.

Gray, M. 2004. Geodiversity: Valuing and Conserving Abiotic Nature. John Wiley \& Sons: Chichester; pp 434.

Hack, J., 1973. Stream profile analysis and stream gradient index, U. S. Geol. Surv. J. Res. 1, pp. 421429.

Hjerdt, K.N, McDonell, J.J, Seibert, J., Rodhe, A., 2004. A new topographic index to quantify downslope controls on local drainage. Water Resources Research, Vol. 40, W05602, pp 1-6.

Hjort, J. and Luoto, M., 2010. Geodiversity of high-latitude landscapes in northern Finland. Geomorphology, 115(1-2), pp. 109-116.

Horton, R.E., 1945.Erosional development of streams and their drainage basins; hydrophysical approach to quantitative morphology. Geol. Soc. Am. Bull. 56, pp. 275-370.

IGME, 1971. Geological Map of Greece, western Crete sheets. Athens:

Institute of Geology and Mineral Exploration. Scale: 1:50,000.

Jamieson, S.S.R., Sinclair, H.D., Kirstein, L.A., Purves, R.S., 2004. Tectonic forcing of longitudinal valleys in the Himalaya: morphological analysis of the Ladakh Batholith, North India. Geomorphology 58, pp 49-65.

Jenness, J.S., 2004. Calculating landscape surface area from digital elevation models. Wildfire Society Bulletin, 32 (3), pp. 829-839.

Keller, E.A., 1986. Investigation of active tectonics: Use of surficial earth processes. In: Wallace, R.E. (Ed.), Active Tectonics. Studies in Geophysics. The National Academies Press, Washington, DC, pp 136147.

Keller, E.A. and Pinter, N., 1996. Active Tectonics (Earthquakes, Uplift and Landscape). Prentice-Hall Inc., New Jersey, pp 339.

Keller, E. A. and Pinter, N., 2002. Active Tectonics: Earthquakes and Landscape. Second Edition. Prentice-Hall: Upper Saddle River, New Jersey, pp 362.

Kelletat, D., 1996. Perspectives in coastal geomorphology of western Crete, Greece. Zeitschrift füer Geomorphologie N. F., Supplement Band 102, pp 1-19.

Köppen, W., 1936. Das geographische System der Klimate. In:Köppen W, Geiger R (eds) Handbuch der Klimato - logie. Gebrüder Borntraeger, Berlin, pp 1-44.

Kostrzewski, A., 2011. The role of relief geodiversity in geomorphology. Geographia Polonica, 84, special issue 2, pp. 69-74.

Kottek, M., Grieser, J., Beck, C., Rudolf, B., Rubel, F., 2006. World map of the Koppen-Geiger climate classification updated, Meteorol. Z., 15, pp 259-263.

Kouli, M., Vallianatos, F., Soupios, P., Alexakis, D., 2007. GIS-based morphometric analysis of two major watersheds, western Crete, Greece, Journal of Environmental Hydrology 15, pp 1-17. 
642

643

644

645

646

647 648

649 650

651

652

653

654 655

656

657

658

Kozlowski S. 2004. Geodiversity. The concept and scope of geodiversity. Przeglad Geologiczny 52(8/2), pp 833-837.

Leopold, L.B., 1969. Quantative comparison of some aesthetic factors among rivers. USGS Circular, 620, pp 16.

Luo W., 1998. Hypsometric analysis with a Geographic Information System. Computers \& Geosciences Vol. 24, No. 8, pp 815-821.

Maidment, D., 2002. Arc Hydro: GIS for Water Resources. Redlands, CA, USA: ESRI Press, Volume 1, 203pp.

Meulenkamp, J.E., Dermitzakis, M.D., Georgiades-Dikeoulia, E., Jonkers, H.A. \& Boger, H., 1979. Field guide to the Neogene of Crete. Publ. of the Department of Geology and Paleontology, Univ. of Athens, ser. A, no32, pp. 32.

McAdoo, B.G., Capone, M.K., and Minder, J., 2004. Seafloor geomorphology of convergent margins: Implications for Cascadia seismic hazard. Tectonics, vol. 23, TC6008, pp. 1-15.

McGarigal, K., Cushman, S.A., Neel, M.C., Ene, E., 2002. FRAGSTATS: Spatial Pattern Analysis Program for Categorical Maps. Computer software program produced by the authors at the University of Massachusetts: Amherst, pp 51.

Mesa, L. M., 2006. Morphometric analysis of a subtropical Andean basin (Tucuman, Argentina). Environ Geol (2006) 50, pp 1235-1242.

Migon, P., Kasprzak, M., Traczyk, A., 2013. How high-resolution DEM based on airborne LIDAR helped to reinterpret landforms - examples from the Sudetes. SW Poland. Landform Anal. 22, pp. 89-101.

Mouslopoulou, V., Moraetis, D., and Fassoulas, Ch., 2011. Identifying past earthquakes on carbonate faults: Advances and limitations of the 'Rare Earth Element' method based on analysis of the Spili Fault, Crete, Greece. Earth and Planetary Science Letters, 309, pp. 45-55.

Mukhopadhyay, S.C., 1984. The Thisa Basin - A Study in Fluvial Geomorphology, K.P. BanchiandCo., Calcutta, pp 308.

Nieto LM. 2001. Geodiversity: proposal of an integrative definition. Boletín Geológico y Minero, 112(2), pp 3-12.

Ollier, C.D., Lawrance, C.J., Webster, R., Beckett, P.H.T., 1969. The Land Systems of Uganda. Report 959, M.E.X.E., Christchurch, UK, pp 234.

Ozdemir, H. and Bird, D., 2009. Evaluation of morphometric parameters of drainage networks derived from topographic maps and DEM in point of floods. Environmental Geology. Volume 56, Issue 7, pp $1405-1415$.

Panizza, M. and Piacente S., 2008. La geodiversità e una sua applicazione nel territorio emiliano. Il Geologo dell'Emilia-Romagna 29, pp 35-37.

Papanikolaou, D. \& Vassilakis, E., 2009. Thrust faults and extensional detachment faults in Cretan tectono-stratigraphy: Implications for Middle Miocene extension. Tectonophysics, Vol. 488, pp. 233247. 
672

673

674

675

676

677 678

679 680

681 682 683

684 685

686

687 688

Papastamatiou, J. \& Reichel, M., 1956. Sur l' age des phyllades de l' ile de Crete. Ecl. Geol. Helv. 49, pp. 147.

Papastamatiou, J., Vetoulis, D., Bornovas, J., Christodoulou. G. \& Katsikatsos, G., 1959. Geologische Karte von Kreta (1:50.000) Blatt Ziros. Inst. Geol. Subsurf. Res., Athens.

Papazachos, B.C. and Comninakis, P.E., 1978. Deep structure and tectonics of the Eastern Mediterranean. Tectonophysics, 33, pp 285-296.

Pareta, K. and Pareta, U., 2011. Quantitaive morphometric analysis of a watershed of Yamuna basin, India using ASTER (DEM) data and GIS. International Journal of Geomatics and Geosciences, vol. 2, no1, pp. 248-269.

Parks, K.E., Mulligan, M., 2010. On the relationship between a resource based measure of geodiversity and broad scale biodiversity patterns. Biodiversity and Conservation, 19, pp. 2751-2766.

Pereira, D.I., Pereira, P., Brilha, J., Santos, L., 2013. Geodiversity assessment of Parana state (Brazil): an innovative approach. Environmental Management, pp. 1-12.

Pike, R.J. and Wilson, S.E., 1971. Elevation-relief ratio, hypsometric integral, and geomorphic areaaltitude analysis. Geological Society of America Bulletin, v.82, pp 1079-1084.

Pirazzoli, P.A., Laborel, J., Stiros, S.C., 1996. Earthquake clustering in the Eastern Mediterranean during historical times. J. Geophys. Res., 101 (B3), pp. 6083-6097.

Pirazzoli, P.A., 2005. A review of possible eustatic, isostatic and tectonic contributions in eight lateHolocene relative sea-level histories from the Mediterranean area. Quaternary Science Reviews 24, pp 1989-2001.

Rawat P., 2013. GIS Modeling on Mountain Geodiversity and its Hydrological Responses: in View of Climate Change. Book by LAP LAMBERT Academic Publishing (May 1, 2013), pp 188.

Reddy, G. P. Obi, Maji, A. K., Gajbhiye, K. S., 2004. Drainage morphometry and its influence on landform characteristics in a basaltic terrain, Central India - a remote sensing and GIS approach. International Journal of Applied Earth Observation and Geoinformation, 6, pp 1-16.

Renz, C., 1955. Dia vomeogene Stratigraphie der normalsedimentaeren Formationen Griechenlands, Inst. Geol. Subsurf. Res., pp. 637.

Rowberry, M.D., 2012. A comparison of three terrain parameters that may be used to identify denudation surfaces within a GIS: a case study from Wales, United Kingdom. Computers \& Geosciences, 43, pp 147158.

Ruban, D., 2010. Quantification of geodiversity and its loss. Proc Geol Assoc, 121, pp. 326-333

Sarris A., Karakoudis S., Bidaki X., Soupios P., 2005. Study of the Morphological Attributes of Crete through the Use of Remote Sensing Techniques. IASME Trans, Issue 6, Vol. 2, pp 1043-1051.

Sarris, A., Fassoulas, Ch., Karathanasi, V., Mertikas, ST., Pyrintsos, St., Savvaidis., A., Soupios, P., Vallianatos, F., 2006. A Web-GIS Portal of the Natural Resources of the island of Crete. ESRI $21^{\text {st }}$ European Conference on ArcGIS Users, Athens, November 7-8, 2006. 
Sarris, A., 2007. Management of landscape \& natural resources through remote sensing \& GIS. The International Society for Optical Engineering, SPIE Newsroom.

Sen, P. K., 1993. Geomorphological analysis of drainage basins. The University of Burdwan, Burdwan.

Seidel, E., 1971. Die Pindos-serie in Westkreta, auf der insel Gavdos und im Kedros-Gebiet (Mittelkreta). N. Jb. Geol. Palaont. Abh., 137, pp. 443-460.

Seidel, E., Kreuzer, H. and Harre, W., 1982. A Late Oligocene/Early Miocene high pressure belt in the external Hellenides. Geol. Jahrb., E 23, pp. 165-206.

Serrano, E. and Flaño, P., 2007. Geodiversity: concept, assessment and territorial application. The case of Tiermes-Caracena. Boletín de la AGE 45, pp 389-393.

Shannon, C.E. and Weaver, W., 1949. The Mathematical Theory of Communication. University of Illinois Press, Urbana.

Sharples, C., 2002. Concepts and principles of geo-conservation. Tasmanian Parks and Wildlife Service web.

Shaw, B., Ambraseys, N. N., England, P. C., Floyd, M. A., Gorman, G. J., Higham, T. F. G., Jackson, J. A., Nocquet, J. M., Pain, C. C., Piggott, M. D., 2008. Eastern Mediterranean tectonics and tsunami hazard inferred from the AD 365 earthquake: Nature Geoscience 1, pp 268-276.

Simpson, E. H., 1949. Measurement of diversity. Nature 163:688.

Singh, S. and Dubey, A., 1994. Geoenvironmental Planning of Watershed in India, Chug publications, Allahabad, India, pp 28-69.

Sorensen, R., Zinko, U., Seibert, J., 2005. On the calculation of the topographic wetness index: evaluation of different methods based on field observations. Hydrology and Earth System Sciences Discussions 2, pp $1807-1834$.

Soupios, P., Sarris, A., Papadakis, G., Papazoglou, M., Vallianatos, F., Makris, J., 2005. Compilation of a Relational Digital Database for Monitoring and Management of Geo-Environmental Data in Crete Region. Proceedings of the 2005 Iasme/Wseas International Conference on Engineering Education, Vouliagmeni, Athens, Greece, July 8-10, 2005, pp 423-430.

Spellerberg, I. and Fedor, P.J., 2003. A tribute to Claude Shannon (1916- 2001) and a plea for more rigorous use of species richness, species diversity and the 'Shannon-Wiener' Index. Global Ecology \& Biogeography 12, pp 177-179.

Sreedevi, P.D., Owais, S., Khan, H.H., Ahmed, S., 2009. Morphometric Analysis of a watershed of South India using SRTM Data and GIS, Journal Geological Society of India, vol. 73, pp 543-552.

Stavi, I., Shem-To, R., Chocron, M., Yizhaq, H., 2015. Geodiversity, self-organization, and health of three-phase semi-arid rangeland ecosystems, in the Israeli Negev. Geomorphology, 234, pp. 11-18.

Stiros, S., 1996. Late Holocene relative sea level changes is SW Crete evidence of an unusual earthquake cycle. Annali di Geofisica, 3, pp. 677-687.

Stiros, S., 2001. The AD 365 Crete earthquake and possible seismic clustering during the fourth to sixth centuries AD in the Eastern Mediterranean: a review of historical and archaeological data. J. Struct. Geol., 23, pp. 545-562. 
Strahler, A.N., 1952. Hypsometric (area-altitude) analysis of erosional topography. Geological Society of 734 America Bulletin 63, pp 1117-1142.

735 Strahler, A.N., 1958. Dimensional analysis applied to fluvial eroded landforms. Geological Society of 736 America Bulletin 69, pp 279-299.

737 Strahler, A.N., 1964. Quantitative geomorphology of basins and channel networks. In: Chow, V.T. (Ed.), 738 Handbook of Applied Hydrology. Mcgraw Hill Book Company, New York.

739 Tarboton, D.C., Bras, R.L., Rodriguea-Iturbe, I., 1988. The fractal nature of river networks. Water $740 \quad$ Resources Research 24 (8), pp. 1317-1322.

741 Toudeshki, V.H. and Arian, M., 2011. Morphotectonic Analysis in the Ghezel Ozan River Basin, NW 742 Iran. Journal of Geography and Geology 3, pp 258-265.

743 Troiani, F. and Della Seta, M., 2008. The use of the Stream Length-Gradient index in morphotectonic 744 analysis of small catchments: A case study from Central Italy. Geomorphology 102, pp 159-168.

745 Tucker, G.E. and Bras, R.L., 1998. Hillslope processes, drainage density, and landscape morphology. 746 Water Resources Research, Vol. 34, No. 10, pp 2751-2764.

747 Verstappen, H.T., 1983. Applied geomorphology. ITC, Enschede.

748 Zavoianu, I., 1985. Morphometry of Drainage Basins. Developments in Water Science, 20, pp. 238.

749

750 Figures and Tables: 
751

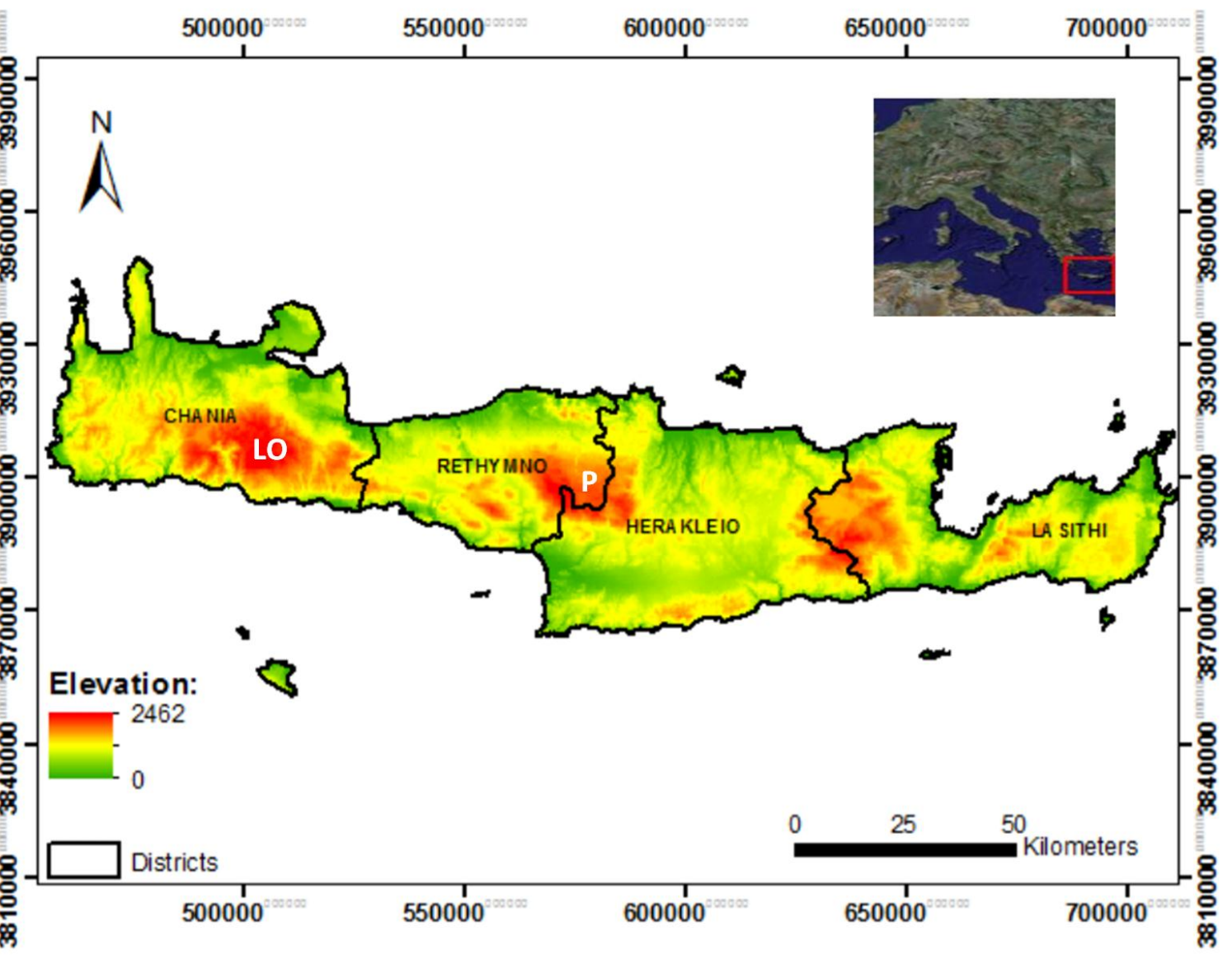

753 Fig. 1. The island of Crete, with red tones highlighting mountainous relief (LO: Lefka Ori; P: Psiloritis). 

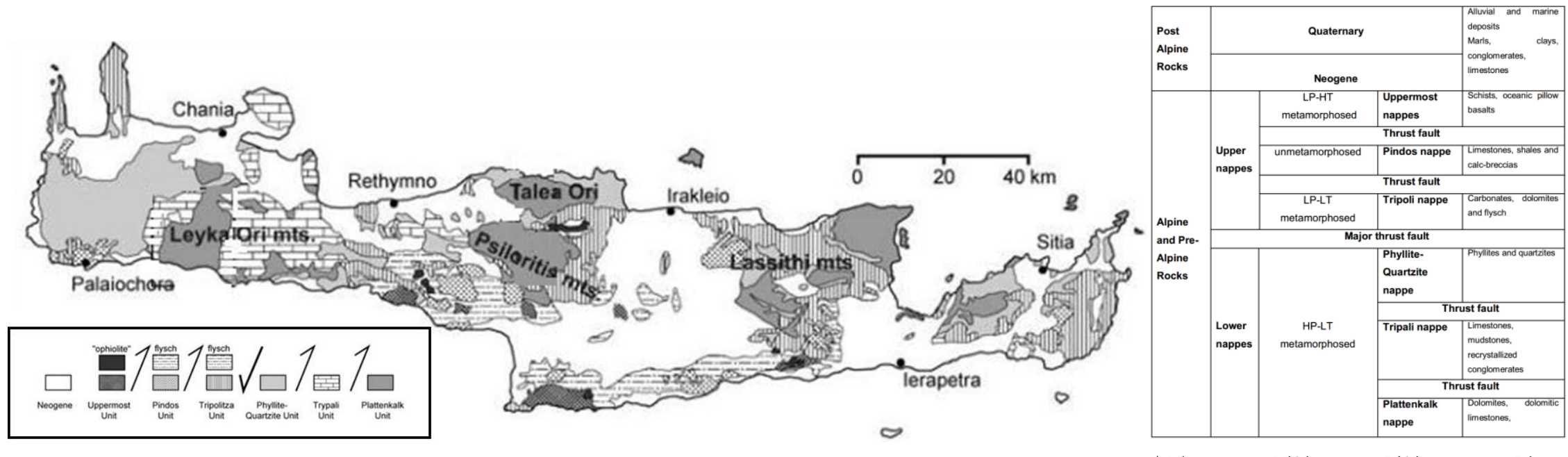

*LP: low pressure; HP: high pressure; HT: high temperature; LT: low temperature

755 Fig. 2. The distribution of the major nappe piles formation across Crete (modified from Fassoulas, 1994 and Chatzaras, 2006). 


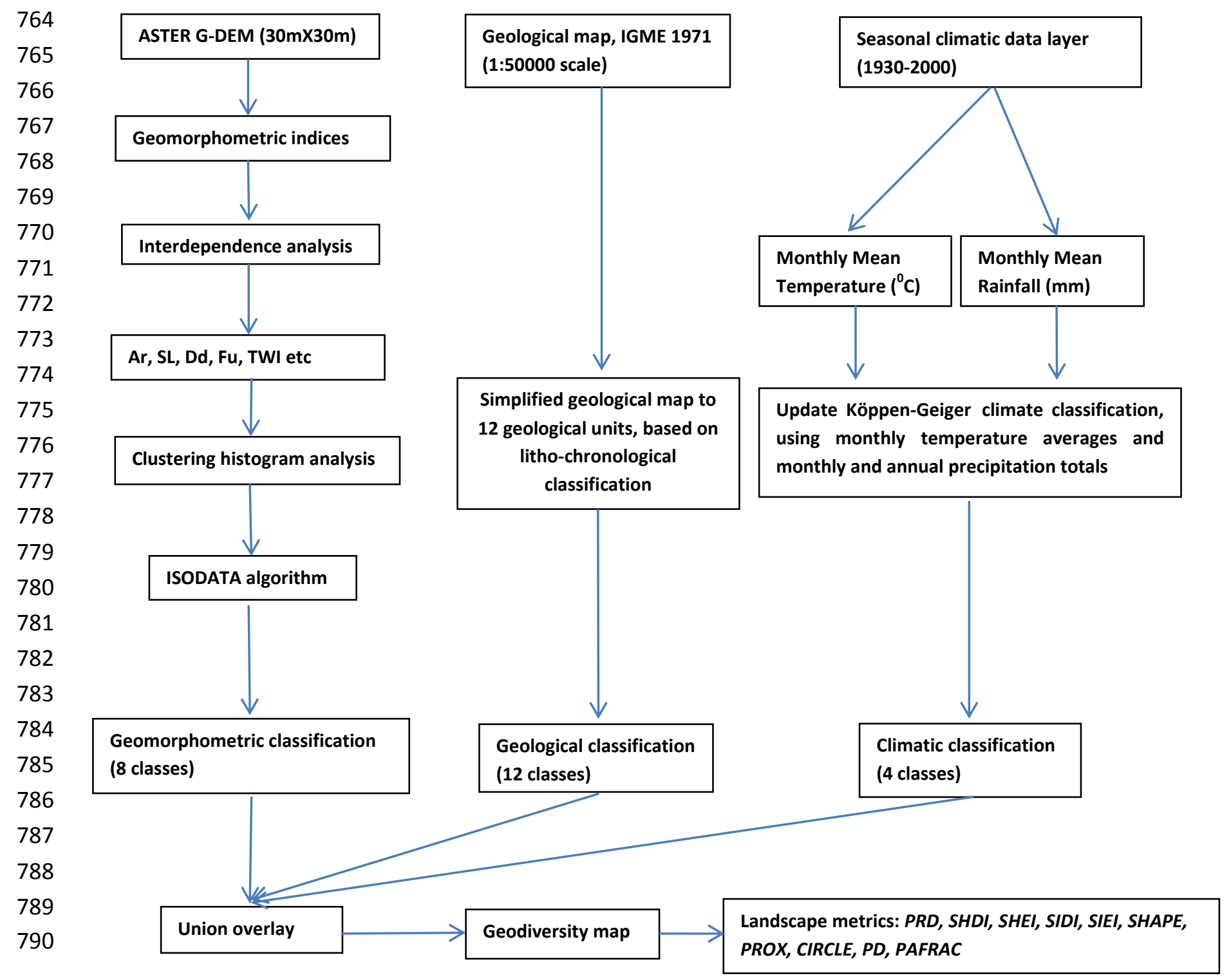

791 Fig. 3. Methodological framework used to assess regional geodiversity in Crete. 


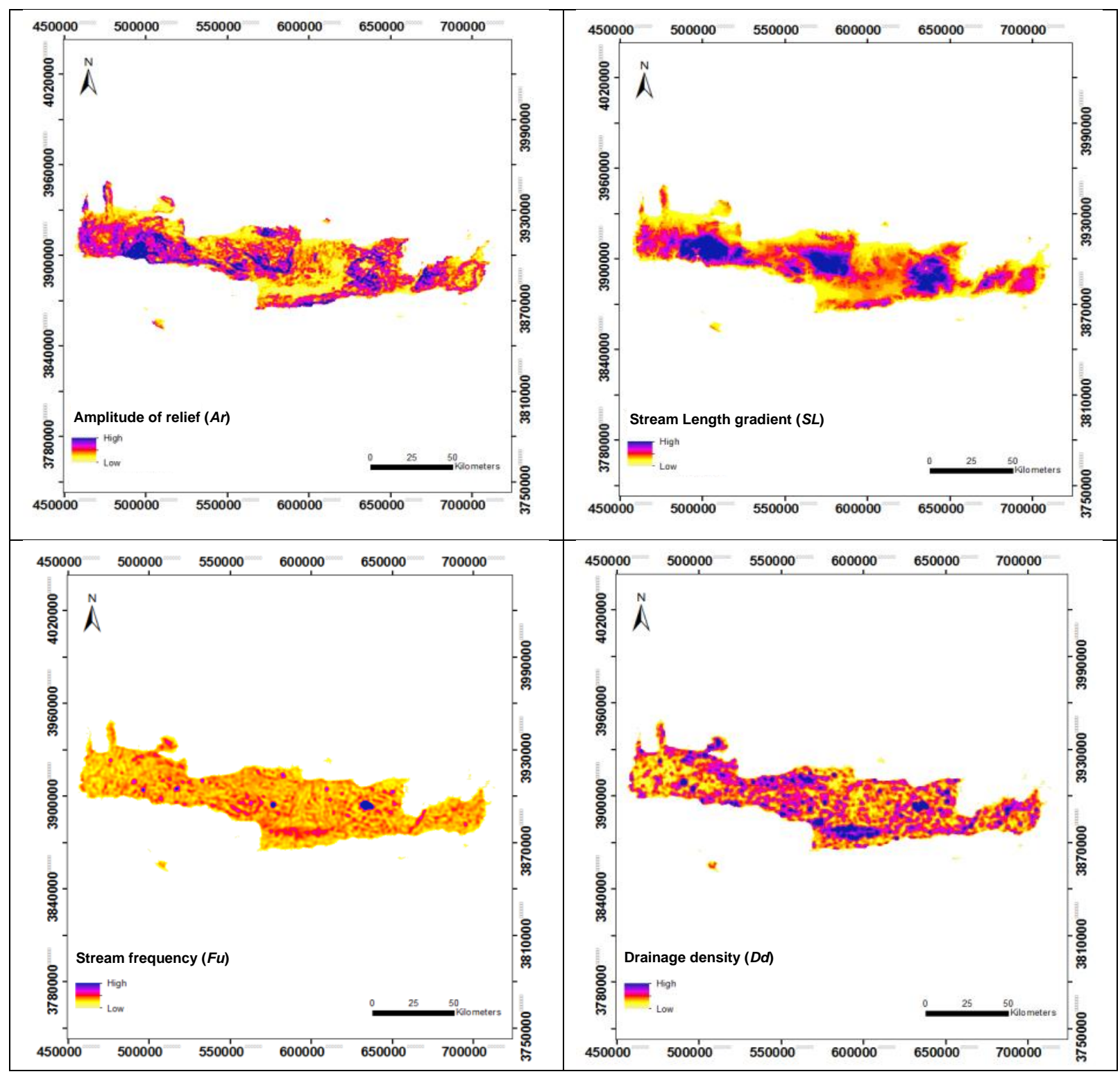




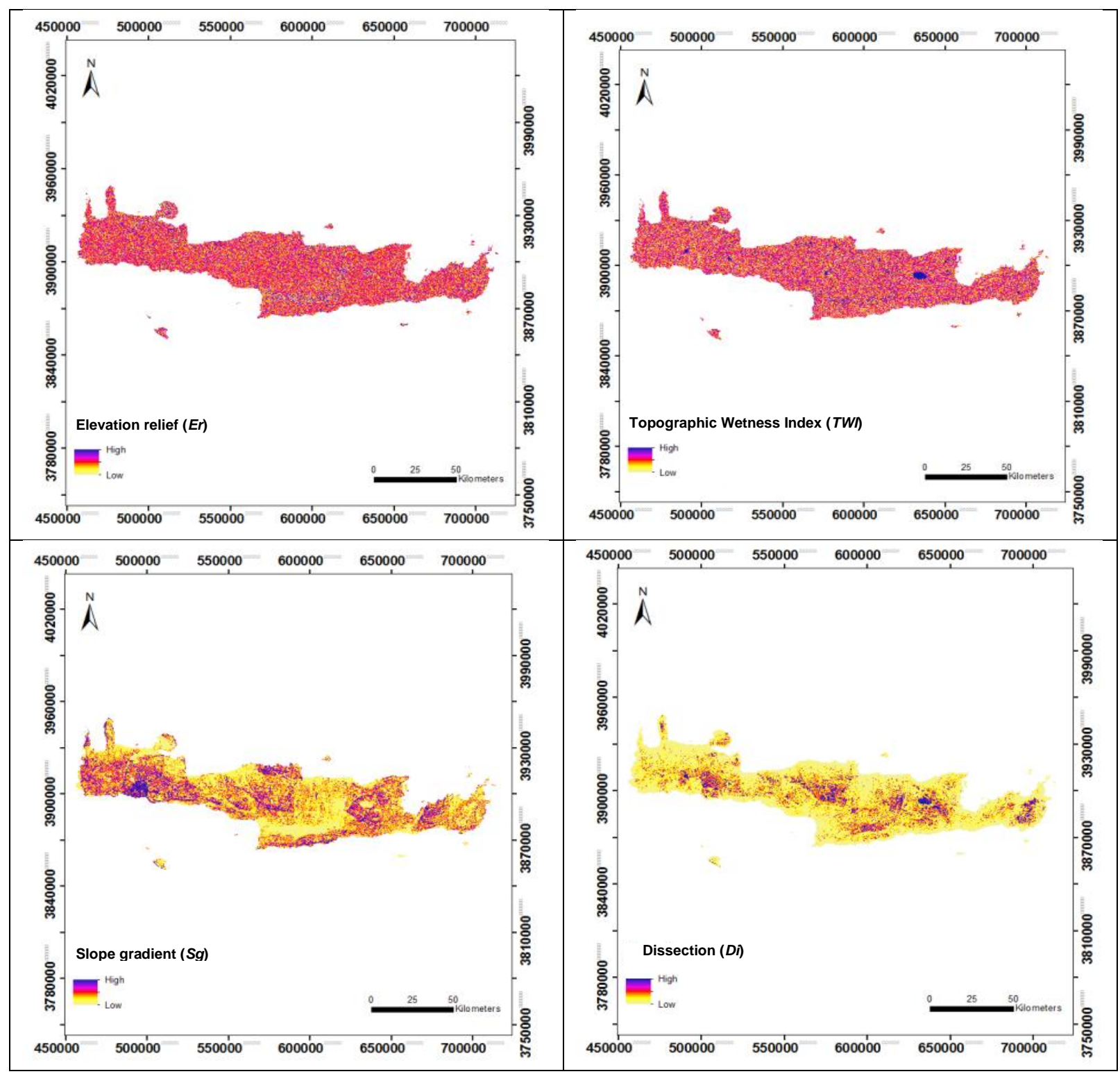




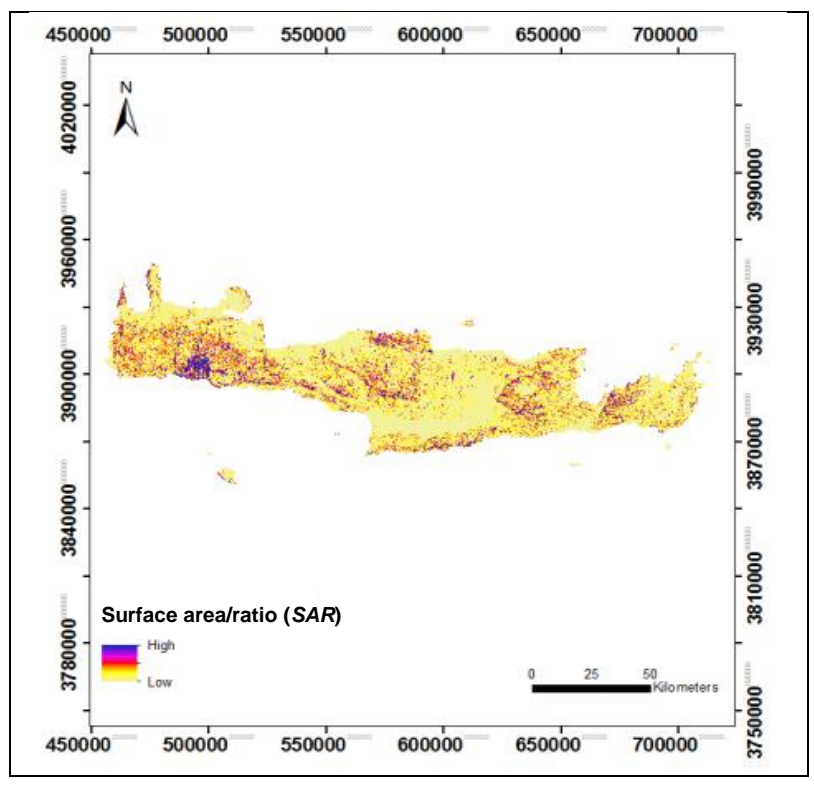

792

793 Fig. 4. The thematic maps of the nine geomorphometric indices that were considered during the geomorphometric classification.

794

795

796

797

798

799

800 
(A)

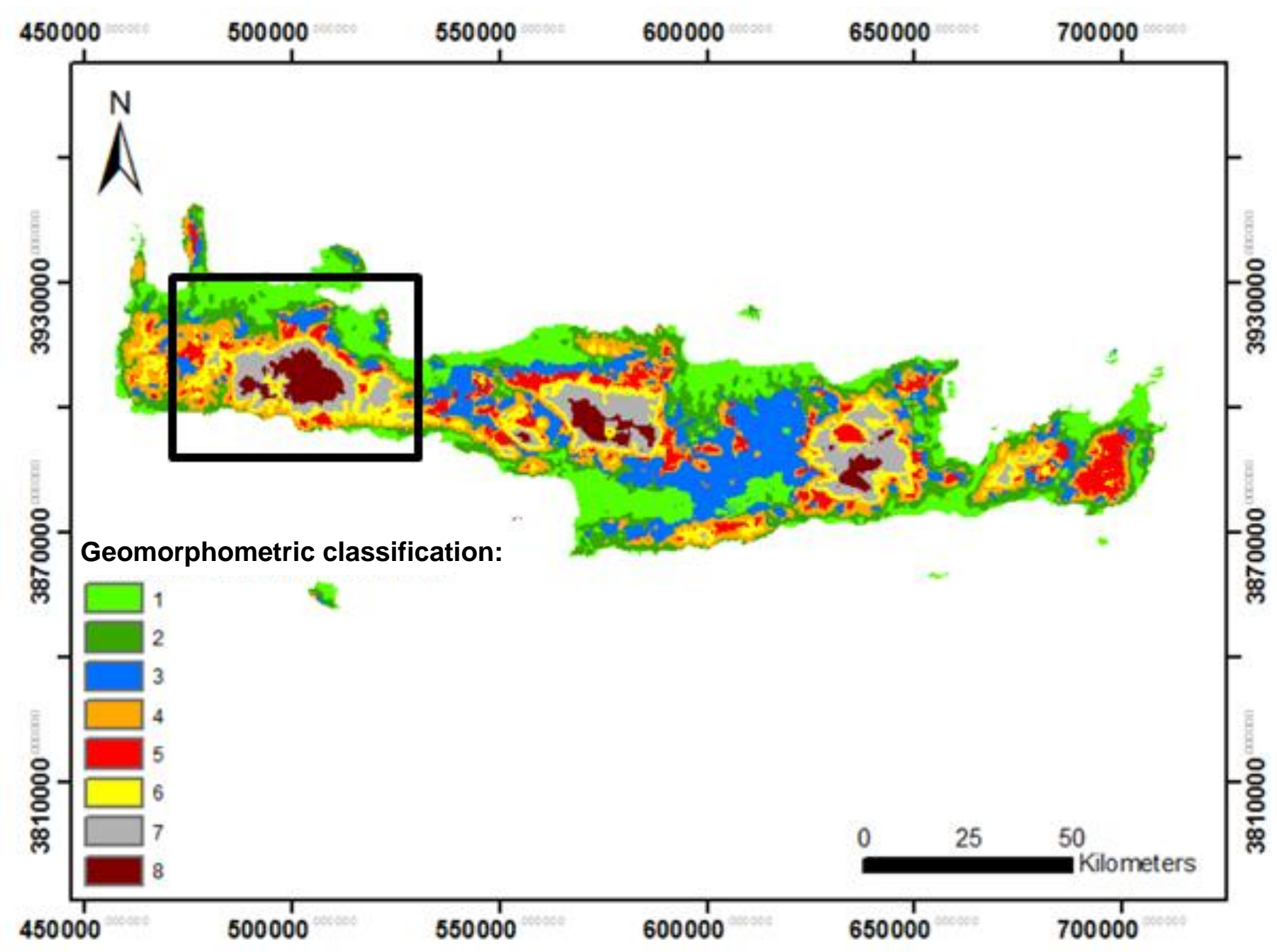

801 
(B)

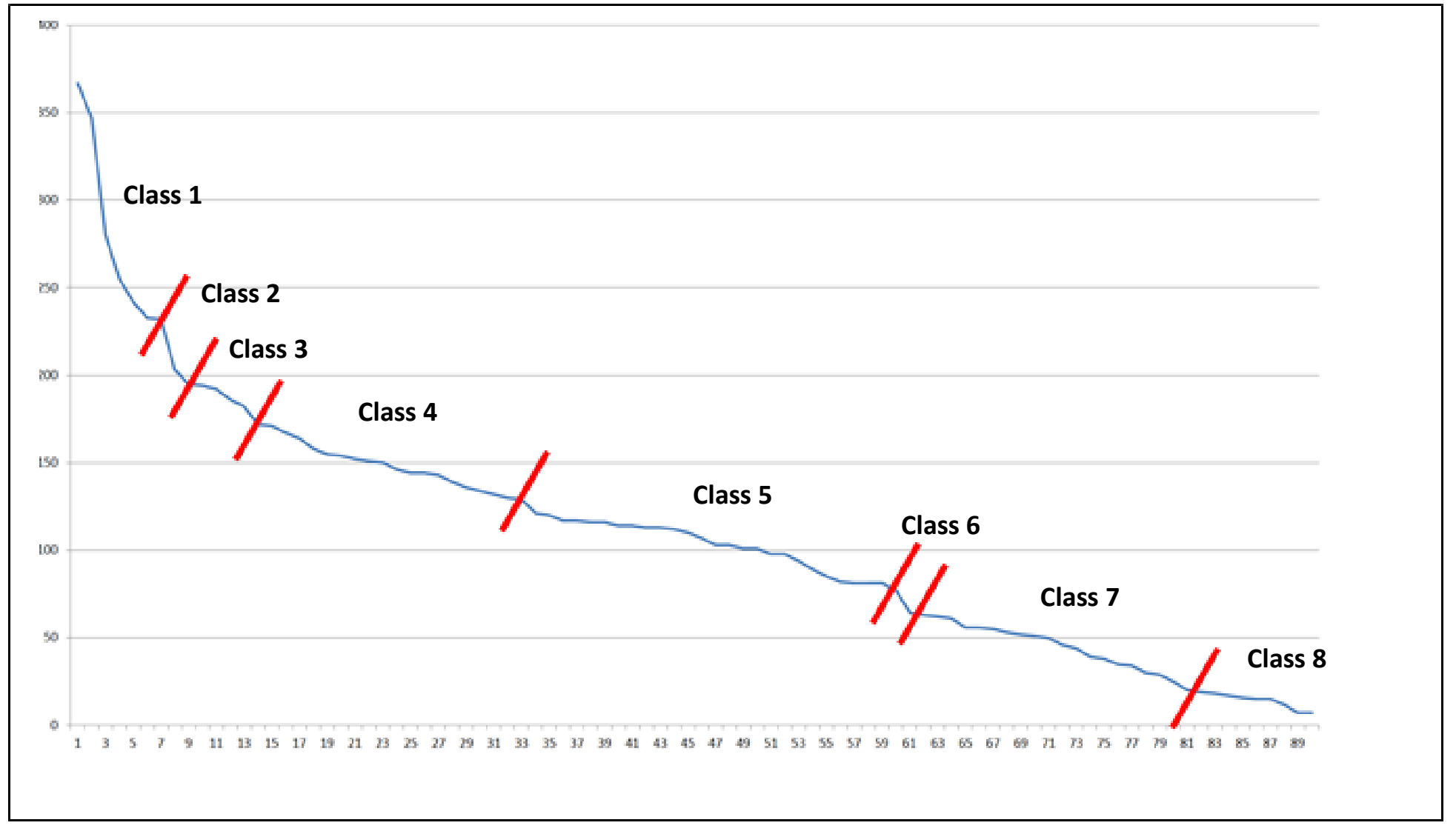

802 
(C)

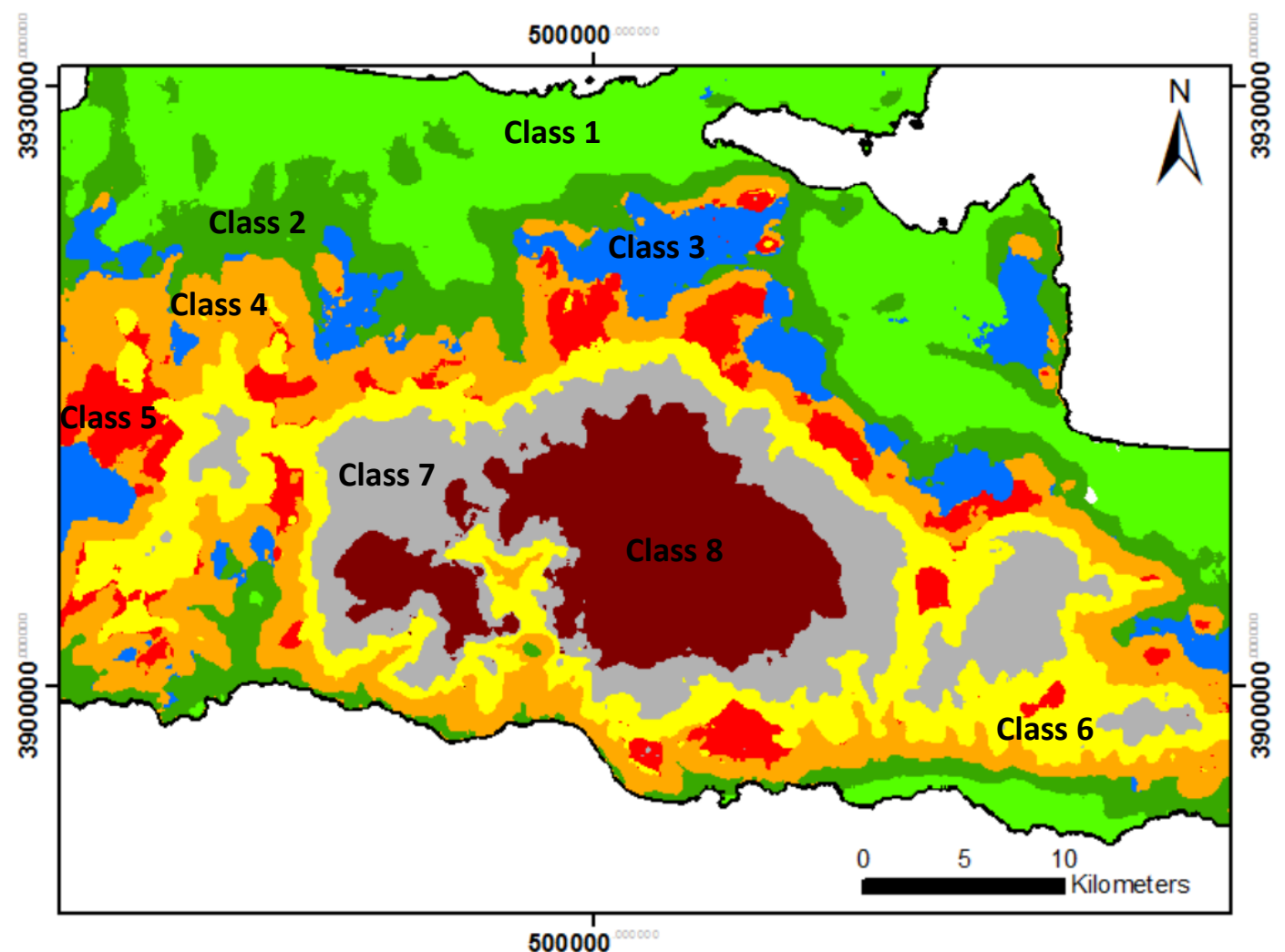

500000

804 Fig. 5 (A): Regional overview of the results for the ISODATA cluster algorithm for the nine selected geomorphometric indices; (B):

805 the eight derived classes as extracted from the discriminated natural breaks of the clustering histogram curve; (C): Zoom-in map 


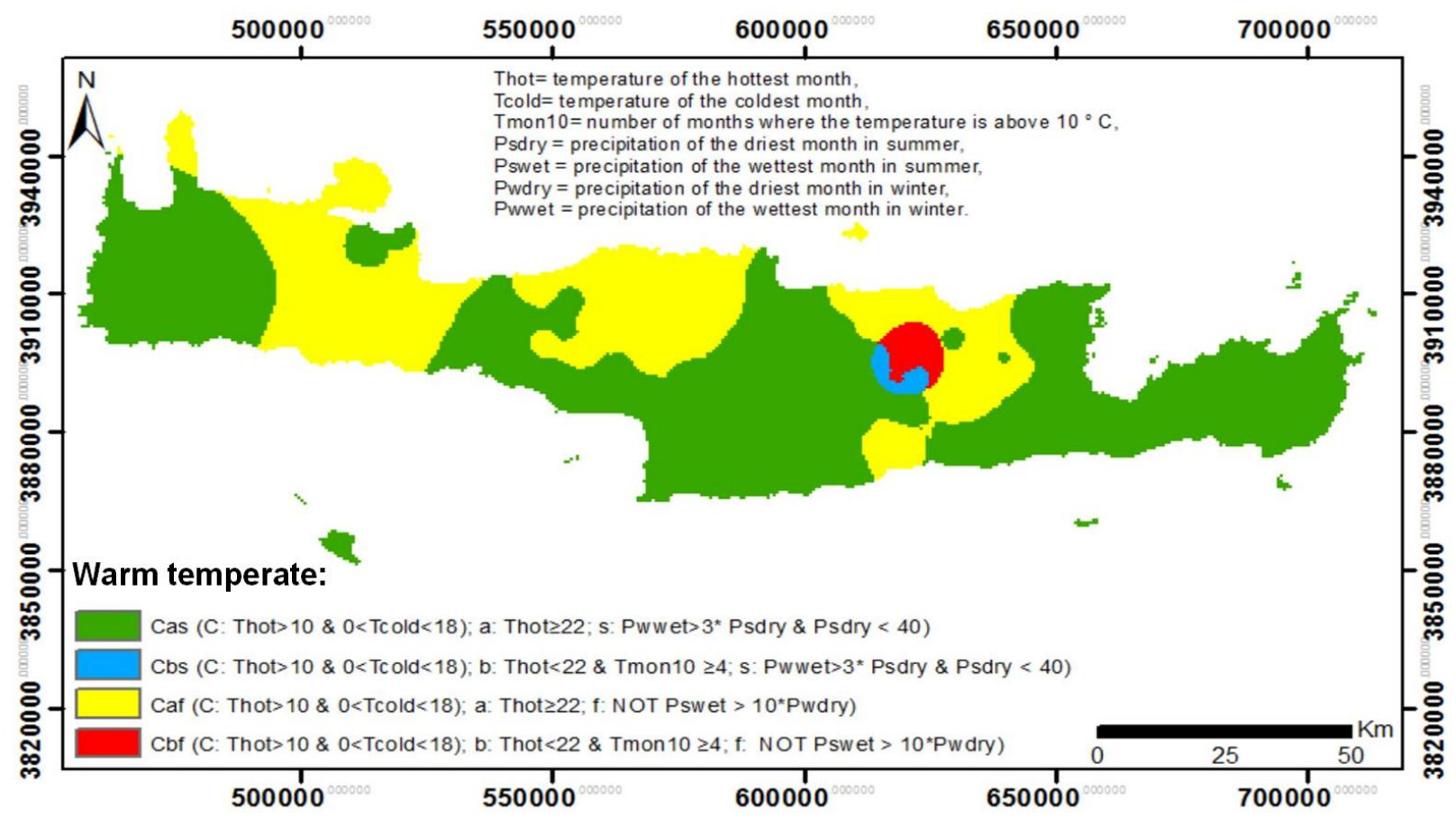

809 50000 550000 600000 650000

810 Fig. 6. Climatic classification, based on precipitation (1930 to 2000) and temperature (1950 to 2000) datasets. The region is

811 characterized as warm temperate climate, described by Cas, Cbs, Caf and Cbf classes. 


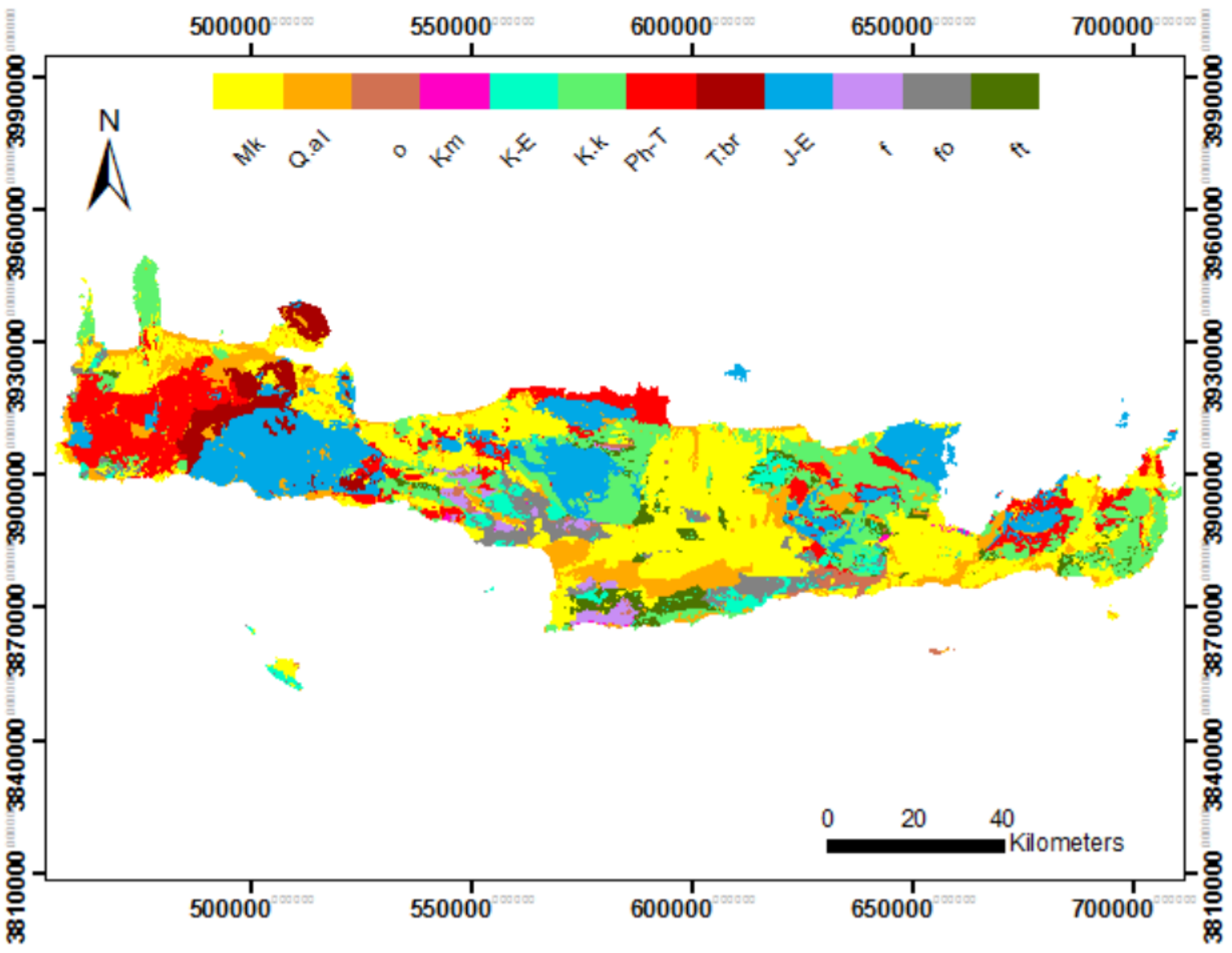

815

816 Fig.7. Simplified geological setting based on the classification of the 74 rock formations to 12 main units after Sarris (2007) and

817 Fassoulas et al. (2007) studies. 


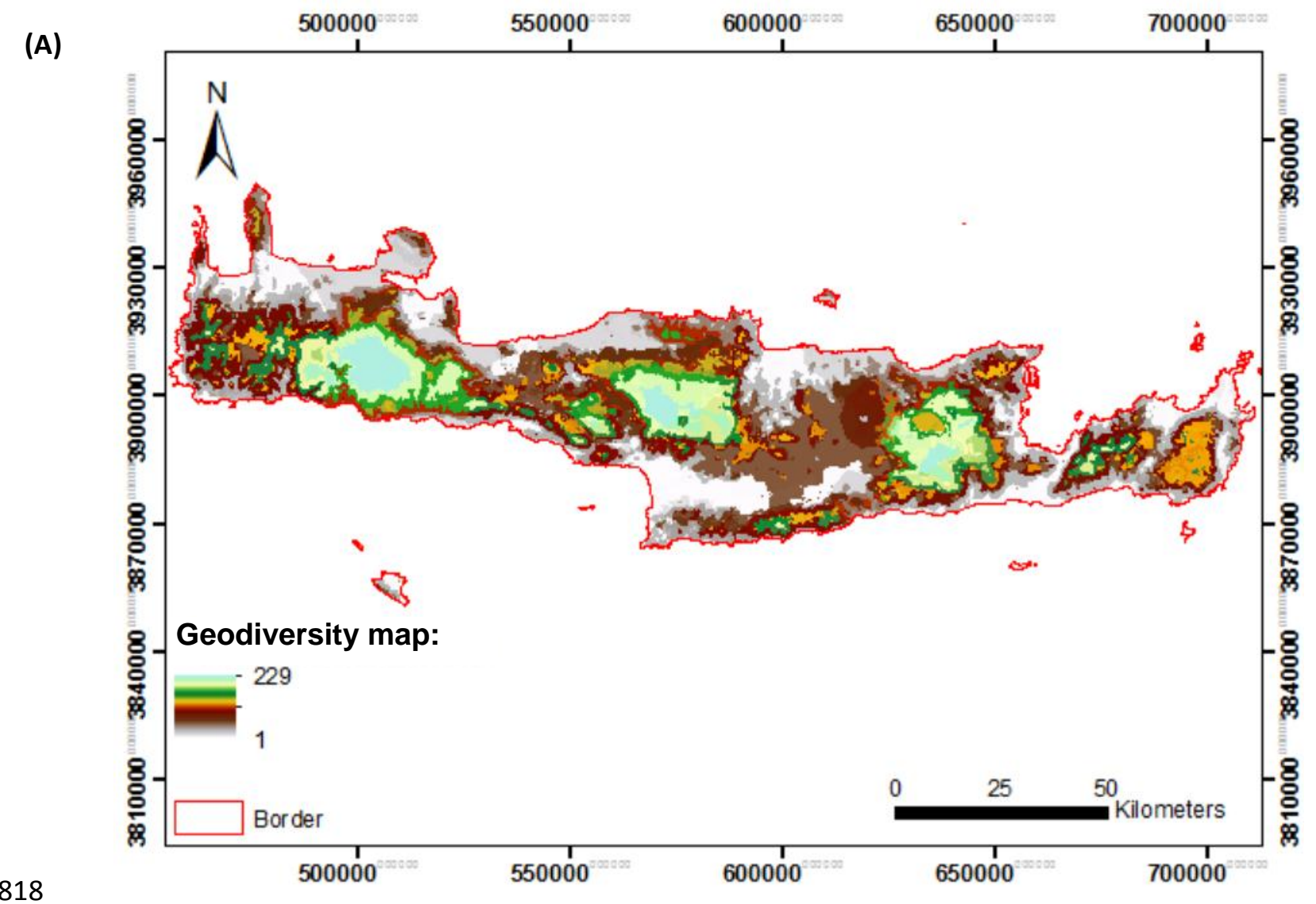


(B)
Percentages of Geomorphometric versus Geological Classes

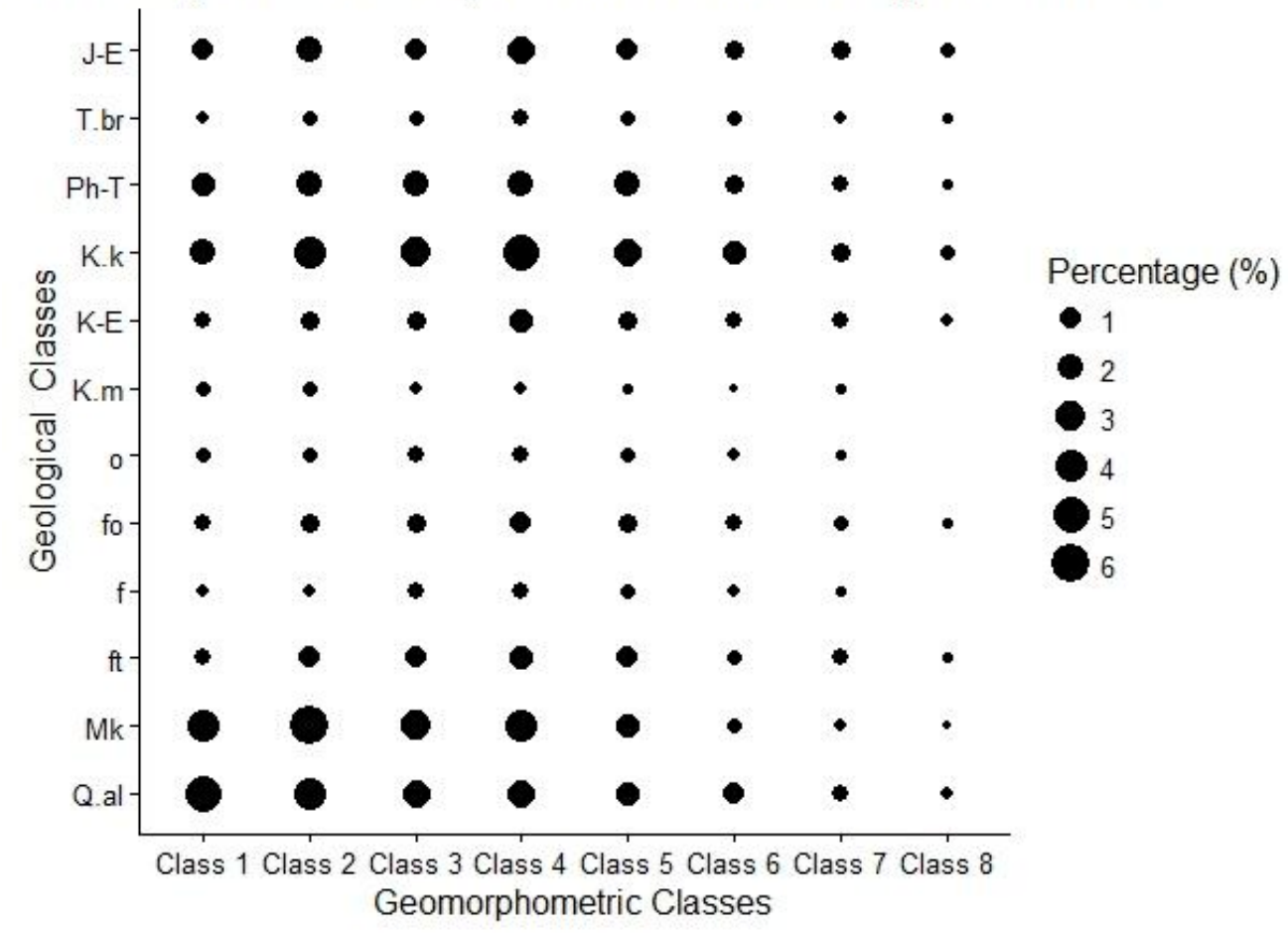




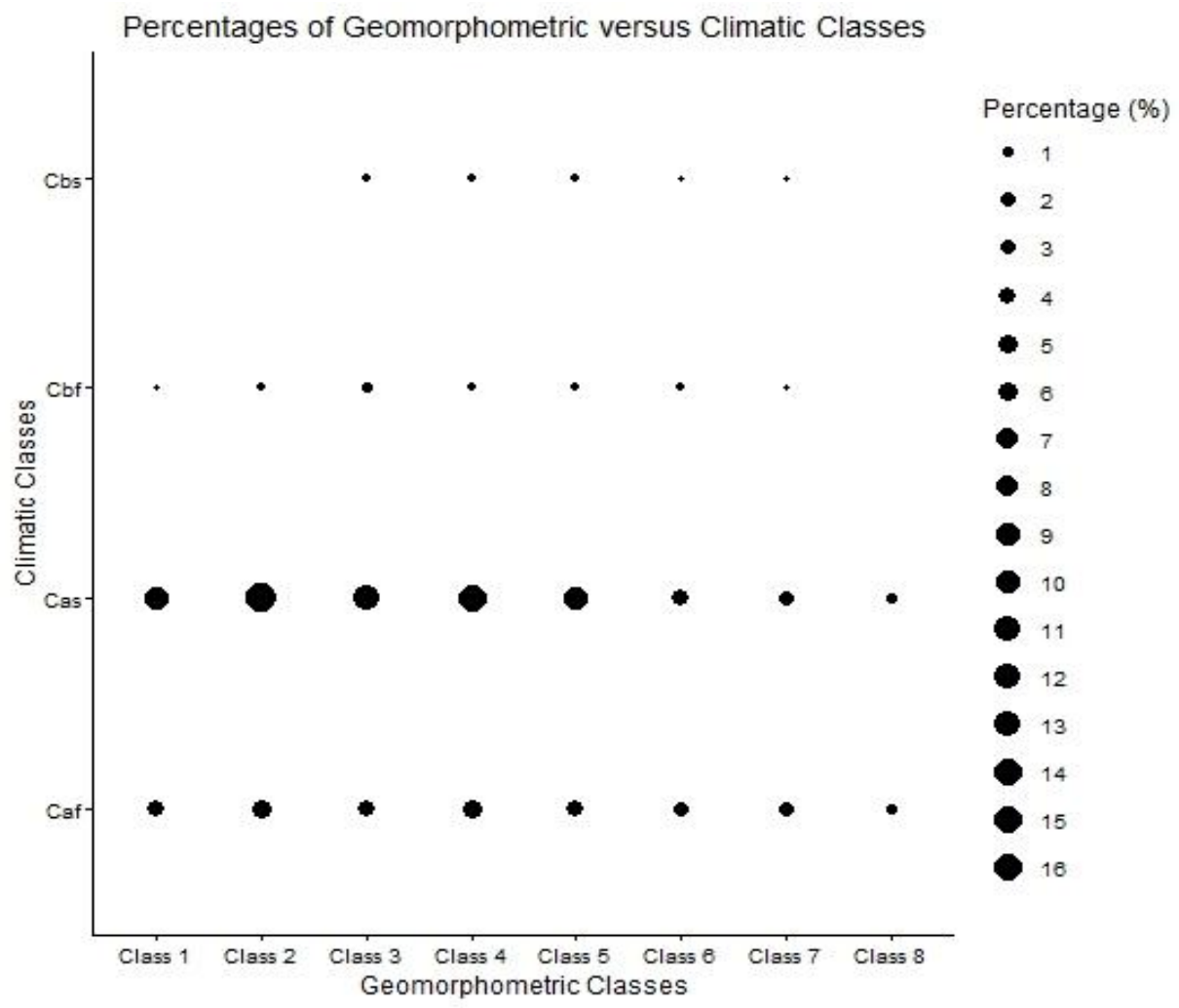




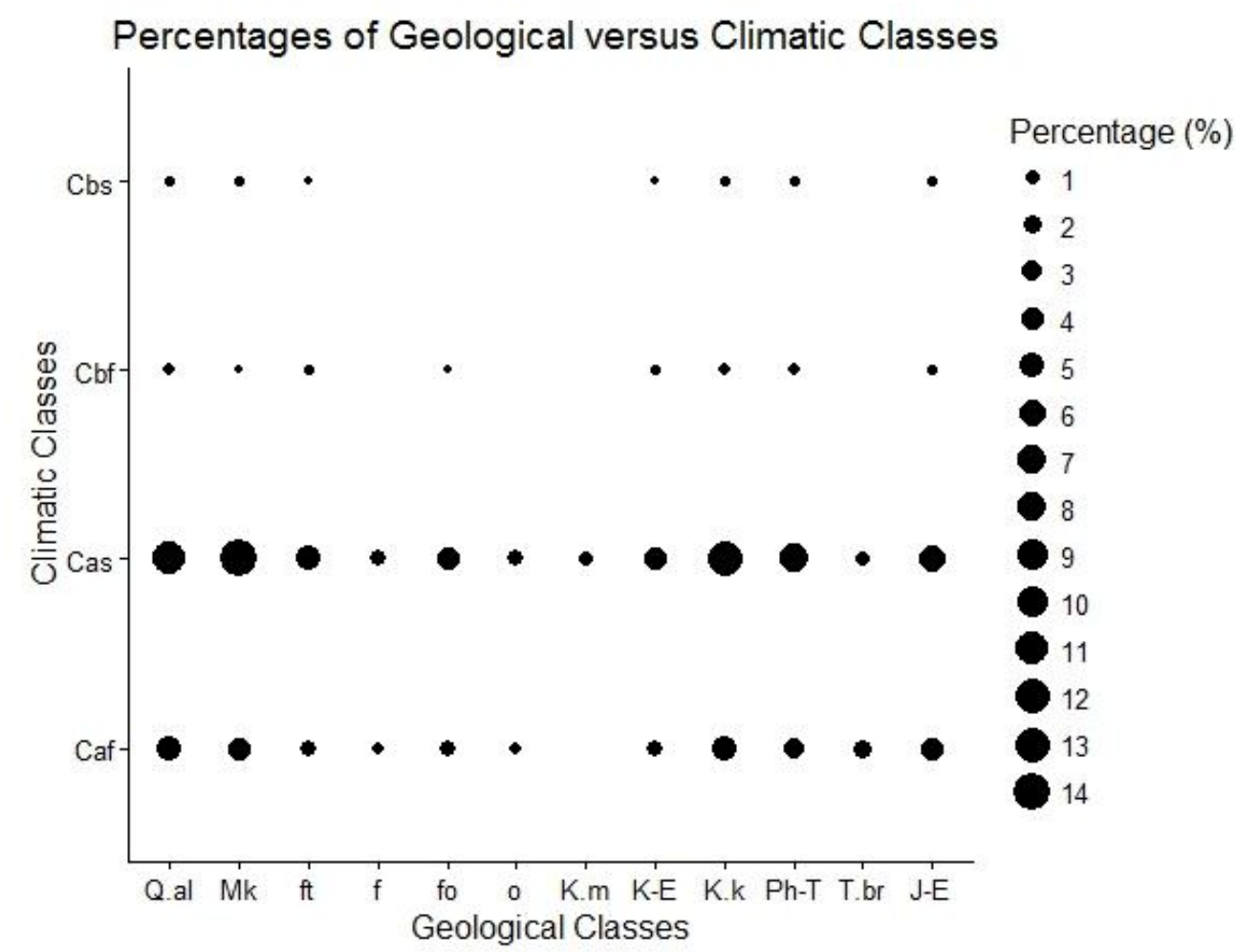

822 Fig. 8. (A) Geodiversity map, based on the union overlay procedure of the geomorphometric, geological and climatic classifications;

823 (B) The occurrences among each of the three classifications acknowledged to the final geodiversity map. 


\begin{tabular}{|c|c|c|c|c|c|c|c|c|c|}
\hline Layer & $\boldsymbol{A} \boldsymbol{r}$ & $\boldsymbol{S L}$ & $\boldsymbol{F u}$ & $\boldsymbol{D d}$ & $\boldsymbol{E r}$ & $\boldsymbol{T W I}$ & $\boldsymbol{S g}$ & $\boldsymbol{S A R}$ & $\boldsymbol{D} \boldsymbol{i}$ \\
\hline $\boldsymbol{A} \boldsymbol{r}$ & 1 & 0.528 & -0.056 & -0.138 & 0.022 & -0.067 & 0.585 & 0.474 & -0.048 \\
\hline $\boldsymbol{S} \boldsymbol{L}$ & 0.528 & 1 & 0.063 & -0.045 & 0.015 & -0.033 & 0.285 & 0.212 & 0.365 \\
\hline $\boldsymbol{F u}$ & -0.056 & 0.063 & 1 & 0.356 & -0.002 & 0.153 & -0.061 & -0.032 & 0.215 \\
\hline $\boldsymbol{D} \boldsymbol{d}$ & -0.138 & -0.045 & 0.356 & 1 & 0.004 & 0.106 & -0.157 & -0.092 & 0.14 \\
\hline $\boldsymbol{E} \boldsymbol{r}$ & 0.022 & 0.015 & -0.002 & 0.004 & 1 & -0.217 & 0.013 & 0.005 & 0.016 \\
\hline $\boldsymbol{T W I}$ & -0.067 & -0.033 & 0.153 & 0.106 & -0.217 & 1 & -0.138 & -0.093 & 0.088 \\
\hline $\boldsymbol{S g}$ & 0.585 & 0.285 & -0.061 & -0.157 & 0.013 & -0.138 & 1 & 0.566 & -0.307 \\
\hline $\boldsymbol{S A R}$ & 0.474 & 0.212 & -0.032 & -0.092 & 0.005 & -0.093 & 0.566 & 1 & -0.133 \\
\hline $\boldsymbol{D} \boldsymbol{i}$ & -0.048 & 0.365 & 0.215 & 0.14 & 0.016 & 0.088 & -0.307 & -0.133 & 1 \\
\hline
\end{tabular}

828 Table 1. Correlation coefficient matrix table highlighting the interdependency of the input dataset layers to be used in the 829 geomorphometric classification. 


\begin{tabular}{|c|c|c|}
\hline Elevation & Class ID & Major geomorphometric units description \\
\hline Low relief & 1 & $\begin{array}{l}\text { Coastal lands, alluvial deposits and plains of low height } \\
\text { (mean: } 108 \mathrm{~m} \text { asl), with gentle slopes (mean: } 7.8^{0} \text { ), fine drainage } \\
\text { texture, low degree of landscape deformation, high moisture } \\
\text { accumulation, low degree of dissection or vertical erosion, very low } \\
\text { roughness. }\end{array}$ \\
\hline Low relief & 2 & $\begin{array}{l}\text { Plains and valleys with mean height } 208 \mathrm{~m} \text { asl, moderate slopes } \\
\text { (mean: } 17^{0} \text { ), very low degree of dissection or vertical erosion, } \\
\text { permeable surface material, high infiltration capacity, moderate } \\
\text { roughness. }\end{array}$ \\
\hline Low relief & 3 & $\begin{array}{l}\text { Hillsides and slope valleys with mean height } 371 \mathrm{~m} \text { asl, gentle } \\
\text { slopes (mean: } 10^{\circ} \text { ), moderate degree of dissection or vertical } \\
\text { erosion, low roughness. }\end{array}$ \\
\hline $\begin{array}{l}\text { Intermediate } \\
\text { relief }\end{array}$ & 4 & $\begin{array}{l}\text { Hillsides and slope valleys with mid heights (mean: } 493 \mathrm{~m} \text { asl), } \\
\text { steep slopes (mean: } 21^{0} \text { ), coarse drainage texture, high degree of } \\
\text { landscape deformation, low degree of dissection or vertical erosion, } \\
\text { high roughness. }\end{array}$ \\
\hline $\begin{array}{l}\text { Intermediate } \\
\text { relief }\end{array}$ & 5 & $\begin{array}{l}\text { Intermediate plateaus and plains (mean: } 617 \mathrm{~m} \text { asl), gentle slopes } \\
\left(\text { mean: } 11^{0}\right) \text {, high moisture accumulation, low degree of landscape } \\
\text { deformation, high degree of dissection or vertical erosion, } \\
\text { impermeable surface material, low infiltration capacity, low } \\
\text { roughness. }\end{array}$ \\
\hline $\begin{array}{l}\text { Intermediate } \\
\text { relief }\end{array}$ & 6 & $\begin{array}{l}\text { Hillsides and slope valleys with mid to high heights (mean: } 838 \mathrm{~m} \\
\text { asl), steep slopes (mean: } 22^{0} \text { ), presence of V-shaped valleys } \\
\text { characterized by high incision, low moisture accumulation and } \\
\text { longitudinal ridges, moderate degree of dissection or vertical } \\
\text { erosion, high roughness. }\end{array}$ \\
\hline High relief & 7 & $\begin{array}{l}\text { Regions with mean height } 1188 \mathrm{~m} \text { asl, steep slopes (mean: } 20^{\circ} \text { ), high } \\
\text { degree of landscape deformation, presence of V-shaped incised } \\
\text { valleys, low moisture accumulation and longitudinal ridges, high } \\
\text { degree of dissection or vertical erosion, high roughness. }\end{array}$ \\
\hline
\end{tabular}




\begin{tabular}{|l|l|l|}
\hline High relief & 8 & $\begin{array}{l}\text { Regions with maximum heights (mean: 1745m asl), steep sloßßes } \\
\text { (mean: } 24^{0} \text { ), high degree of landscape deformation, presence of V- } \\
\text { shaped incised valleys, low moisture accumulation and longitudinal } \\
\text { ridges, very high degree of dissection or vertical erosion, maxinum } \\
\text { roughness. }\end{array}$ \\
\hline
\end{tabular}

Table 2. Final geomorphometric classification and description of the eight major geomorphometric classes obtained after the

\begin{tabular}{|c|c|c|c|c|}
\hline $\mathbf{1}^{\text {st }}$ & $\mathbf{2}^{\text {nd }}$ & $\mathbf{3}^{\text {rd }}$ & Description & Criteria* $^{*}$ \\
\hline C & & & Warm temperate & \\
\hline & & & climate & $\mathrm{T}_{\text {hot }} \geq 22^{0}$ \\
\hline & b & & Hot Summer & Not (a) \& $\mathrm{T}_{\text {mon 10 }} \geq 4^{0}$ \\
\hline & & $\mathrm{s}$ & Dry Summer & $\mathrm{P}_{\text {sdry }}<40 \mathrm{~mm} \& \mathrm{P}_{\text {sdry }}<\mathrm{P}_{\text {wwet }} / 3$ \\
\hline & & $\mathrm{w}$ & Dry Winter & $\mathrm{P}_{\mathrm{wdry}}<\mathrm{P}_{\text {swet }} / 10$ \\
\hline & & $\mathrm{f}$ & Without dry season & Not $(\mathrm{Cs})$ or $(\mathrm{Cw})$ \\
\hline
\end{tabular}

Table 3. Updated Koppen-Geiger classification based on climate types and defining criteria (after Kottek et al., 2006). *: $T_{\text {hot }}=$ temperature of the hottest month; $\mathrm{P}_{\text {sdry }}=$ precipitation of the driest month in summer; $\mathrm{P}_{\mathrm{wdry}}=$ precipitation of the driest month in winter;

$844 \mathrm{P}_{\text {swet }}=$ precipitation of the wettest month in summer; $\mathrm{P}_{\mathrm{wwet}}=$ precipitation of the wettest month in winter; $\mathrm{T}_{\text {mon } 10}=$ number of months 845 where the temperature is above $10^{0}$. 


\begin{tabular}{|c|c|c|c|c|c|c|c|c|c|c|}
\hline \multirow[b]{2}{*}{ Age } & \multirow[b]{2}{*}{ Geological units } & \multicolumn{8}{|c|}{ Geomorphometric classes percentage (\%) for each geological unit } & \multirow[b]{2}{*}{$\begin{array}{c}\text { Total area coverage (\%) of } \\
\text { each geological unit }\end{array}$} \\
\hline & & Class 1 & Class 2 & Class 3 & Class 4 & Class 5 & Class 6 & Class 7 & Class 8 & \\
\hline Cenozoic & Quaternary (Q.al) & 55.6 & 12.13 & 15.48 & 6.44 & 5.51 & 2.34 & 2.4 & 0.06 & 11.01 \\
\hline Cenozoic & Neogene (Mk) & 38.07 & 20.84 & 26.77 & 6.88 & 4.82 & 1.51 & 1.09 & 0.0005 & 29.08 \\
\hline Cenozoic & Flysch Tripolis zone (ft) & 3.64 & 22.15 & 24.91 & 20.59 & 11.51 & 11.23 & 5.2 & 0.76 & 3.31 \\
\hline Mesozoic & $\begin{array}{c}\text { Flysch-Schist allochthonous } \\
\text { series }(f)\end{array}$ & 10.92 & 26.53 & 19.27 & 28.36 & 9.72 & 5.02 & 0.15 & - & 1.42 \\
\hline Mesozoic & Flysch Pindos zone (fo) & 6.85 & 25.92 & 17.97 & 32.24 & 8.84 & 6.33 & 1.57 & 0.24 & 3.81 \\
\hline Mesozoic & $\begin{array}{c}\text { Ophiolites allochthonous } \\
\text { series }(0)\end{array}$ & 7.73 & 18.48 & 14.76 & 34.37 & 20.68 & 3.37 & 0.57 & - & 1.13 \\
\hline Mesozoic & $\begin{array}{c}\text { Carbonate allochthonous } \\
\text { series }(K . m)\end{array}$ & 28.53 & 42.5 & 3.71 & 2.23 & 1.2 & 1.01 & 20.81 & - & 0.16 \\
\hline Mesozoic & Carbonate Pindos zone (K-E) & 2.82 & 13.92 & 19.36 & 21.52 & 4.81 & 19.9 & 13.34 & 4.3 & 3.01 \\
\hline Mesozoic & Carbonate Tripolis zone $(K . k)$ & 7.48 & 16.04 & 10.42 & 21.6 & 11.64 & 12.16 & 14.9 & 5.73 & 15.1 \\
\hline Mesozoic & Phyllite-Quartzite series $(P h-T)$ & 7.84 & 23.39 & 11.28 & 32.29 & 8.39 & 14.13 & 2.6 & 0.04 & 12.15 \\
\hline Mesozoic & Carbonate Tripali zone $(T-B r)$ & 11.32 & 13.4 & 12.01 & 14.96 & 6.75 & 17.48 & 20.21 & 3.84 & 3.61 \\
\hline Palaeozoic & Plattenkalk nappe (J-E) & 3.8 & 10.24 & 6.4 & 17.37 & 5.99 & 17.52 & 21.34 & 17.31 & 16.21 \\
\hline
\end{tabular}

847

848

849

850

851

852

Table 4. The geomorphometric classes areal distribution over each of the twelve geological units and the total area coverage (\%) of each geological unit across Crete. 


\begin{tabular}{|c|c|c|}
\hline $\begin{array}{c}\text { Landscape } \\
\text { metric }\end{array}$ & Range & Description \\
\hline $\begin{array}{l}\text { Patch Richness } \\
\text { Density }(P R D)\end{array}$ & $\boldsymbol{P R \boldsymbol { D }}>0$, without limit & $\begin{array}{l}P R D \text { equals the number of different patch classes present } \\
\text { within the landscape boundary, divided by total landscape } \\
\text { area }\left(\mathrm{m}^{2}\right) \text {, multiplied by } 10000 \text { and } 100 \text { (to convert to } 100 \\
\text { hectares). } \\
\text { It standardizes richness to a per area basis that facilitates } \\
\text { comparison of landscapes. }\end{array}$ \\
\hline $\begin{array}{l}\text { Shannon's } \\
\text { Diversity Index } \\
\text { (SHDI) }\end{array}$ & $\begin{array}{l}S H D I \geq 0, \text { without limit } \\
S H D I=0, \text { when the landscape contains only one patch (no diversity) }\end{array}$ & $\begin{array}{l}\text { SHDI equals minus the sum, across all patch classes, of the } \\
\text { proportional abundance of each patch class multiplied by } \\
\text { that proportion. } \\
\text { It increases as the number of different patch classes } \\
\text { increases and the proportional distribution of area among } \\
\text { patch classes becomes more equitable. }\end{array}$ \\
\hline $\begin{array}{l}\text { Simpson's } \\
\text { Diversity Index } \\
\text { (SIDI) }\end{array}$ & $\begin{array}{l}0 \leq S I D I \leq 1, \\
S I D I=0, \text { when the landscape contains only one patch (no diversity) }\end{array}$ & $\begin{array}{l}\text { SIDI equals } 1 \text { minus the sum, across all patch classes, of the } \\
\text { proportional abundance of each patch class squared. } \\
\text { It increases as the number of different patch classes } \\
\text { increases and the proportional distribution of area among } \\
\text { patch classes becomes more equitable. Represents the } \\
\text { probability that any two pixels selected at random would be } \\
\text { different patch classes. }\end{array}$ \\
\hline $\begin{array}{l}\text { Shannon's } \\
\text { Evenness Index } \\
(\text { SHEI) }\end{array}$ & $\begin{array}{l}0 \leq S H E I \leq 1, \\
S H D I=0 \text {, when the landscape contains only one patch (no diversity), } \\
\text { while approaches } 0 \text { as the distribution of area among the different } \\
\text { patch classes becomes increasingly uneven; } \\
S H D I=1 \text {, when distribution of area among patch classes is perfectly } \\
\text { even (proportional abundances are the same) }\end{array}$ & $\begin{array}{l}\text { SHEI equals minus the sum, across all patch classes, of the } \\
\text { proportional abundance of each patch type multiplied by } \\
\text { that proportion, divided by the logarithm of the number of } \\
\text { patch classes. } \\
\text { It is expressed such that an even distribution of area among } \\
\text { patch classes results in maximum evenness. Evenness is the } \\
\text { compliment of dominance. }\end{array}$ \\
\hline $\begin{array}{l}\text { Simpson's } \\
\text { Evenness Index } \\
\text { (SIEI) }\end{array}$ & $\begin{array}{l}0 \leq S I E I \leq 1, \\
S I E I=0 \text {, when the landscape contains only one patch (no diversity), it } \\
\text { approaches } 0 \text { as the distribution of area among the different patch } \\
\text { classes becomes increasingly uneven; } \\
\text { SIEI=1, when distribution of area among patch classes is perfectly } \\
\text { even }\end{array}$ & $\begin{array}{l}\text { SIDI equals } 1 \text { minus the sum, across all patch classes, of the } \\
\text { proportional abundance of each patch type squared, divided } \\
\text { by } 1 \text { minus } 1 \text {, divided by the number of patch classes. } \\
\text { It is expressed such that an even distribution of area among } \\
\text { patch classes results in maximum evenness. Evenness is the } \\
\text { compliment of dominance. }\end{array}$ \\
\hline $\begin{array}{l}\text { Shape index } \\
\text { (SHAPE) }\end{array}$ & $\begin{array}{l}\text { SHAPE } \leqq 1 \text {, without limit. } \\
\text { SHAPE }=1 \text { when the patch is square and increases without limit as } \\
\text { patch shape becomes more irregular. }\end{array}$ & $\begin{array}{l}\text { Equals patch perimeter }(\mathrm{m}) \text { divided by the square root of } \\
\text { patch area }\left(\mathrm{m}^{2}\right) \text {, adjusted by a constant to adjust for a } \\
\text { square standard. }\end{array}$ \\
\hline $\begin{array}{l}\text { Proximity index } \\
(P R O X)\end{array}$ & $\begin{array}{l}P R O X \geq 0, \\
P R O X=0 \text {, if a patch has no neighbors of the same patch type within } \\
\text { the specified search radius. PROX increases as the neighborhood } \\
\text { (defined by the specified search radius) is increasingly occupied by } \\
\text { patches of the same type and as those patches become closer and } \\
\text { more contiguous (or less fragmented) in distribution. The upper limit } \\
\text { of } \boldsymbol{P R O X} \text { is affected by the search radius and the minimum distance } \\
\text { between patches. }\end{array}$ & $\begin{array}{l}\text { Equals the sum of patch area }\left(\mathrm{m}^{2}\right) \text { divided by the nearest } \\
\text { edge-to-edge distance squared }\left(\mathrm{m}^{2}\right) \text { between the patch and } \\
\text { the focal patch of all patches of the corresponding patch } \\
\text { type whose edges are within a specified distance }(\mathrm{m}) \text { of the } \\
\text { focal patch. Note, when the search buffer extends beyond } \\
\text { the landscape boundary, only patches contained within the } \\
\text { landscape are considered in the computations. In addition, } \\
\text { note that the edge-to-edge distances are from cell center to } \\
\text { cell center. }\end{array}$ \\
\hline $\begin{array}{l}\text { Related } \\
\text { circumscribing }\end{array}$ & 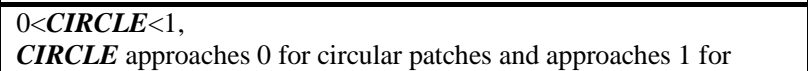 & $\begin{array}{l}\text { Equals } 1 \text { minus patch area }\left(\mathrm{m}^{2}\right) \text { divided by the area }\left(\mathrm{m}^{2}\right) \text { of } \\
\text { the smallest circumscribing circle. }\end{array}$ \\
\hline
\end{tabular}




\begin{tabular}{|c|c|c|}
\hline circle $(C I R C L E)$ & elongated linear patches. & 854 \\
\hline $\begin{array}{l}\text { Perimeter-area } \\
\text { fractal } \\
\text { dimension } \\
(P A F R A C)\end{array}$ & $\begin{array}{l}1 \leqq \boldsymbol{P A F R A C} \leqq 2, \\
\text { A fractal dimension greater than } 1 \text { for a } 2 \text {-dimensional landscape } \\
\text { mosaic indicates a departure from a Euclidean geometry (i.e., an } \\
\text { increase in patch shape complexity). PAFRAC approaches } 1 \text { for } \\
\text { shapes with very simple perimeters such as squares, and approaches } \\
2 \text { for shapes with highly convoluted, plane-filling perimeters. }\end{array}$ & $\begin{array}{l}\text { Equals } 2 \text { divided by the slope of regression line obtained by } \\
\text { regressing the logarithm of patch area }\left(\mathrm{m}^{2}\right) \text { against the } \\
\text { logarithm of patch perimeter }(\mathrm{m}) \text {. That is, } 2 \text { divided by } 855 \\
\text { coefficient b1 derived from a least squares regression fit to } \\
\text { the following equation: } \ln (\text { area })=b_{0}+b_{1} \ln (\text { perim }) \text {. N } 856 \\
\text { PAFRAC excludes any background patches. }\end{array}$ \\
\hline $\begin{array}{l}\text { Patch density } \\
(P D)\end{array}$ & $\begin{array}{l}\boldsymbol{P D}>0 \text {, constrained by cell size. } \\
\boldsymbol{P D} \text { is ultimately constrained by the grain size of the raster image, } \\
\text { because the maximum } \boldsymbol{P D} \text { is attained when every cell is a separate } \\
\text { patch. It expresses number of patches on a per unit area basis that } \\
\text { facilitates comparisons among landscapes of varying size. }\end{array}$ & $\begin{array}{l}\text { Equals the number of patches in the landscape divid85 } 7 \mathrm{y} \\
\text { total landscape area }\left(\mathrm{m}^{2}\right) \\
858\end{array}$ \\
\hline
\end{tabular}

860 Table 5. Landscape metrics with descriptive details of each index.

861

862

863

864

865

866

867

868

869

870

871 


\begin{tabular}{|c|c|c|c|c|c|c|c|c|c|c|c|c|c|c|c|}
\hline \multirow{2}{*}{\multicolumn{2}{|c|}{ (a) }} & \multirow{2}{*}{$\begin{array}{c}\text { Area } \\
\left(\mathbf{k m}^{2}\right)\end{array}$} & \multicolumn{13}{|c|}{ Landscape and patch metrics (Geodiversity map) } \\
\hline & & & $P R D$ & SHDI & SIDI & SHEI & SIEI & $N P$ & $P D$ & $L S I$ & SHAPE & CIRCLE & PAFRAC & PROX & COHESION \\
\hline \multicolumn{2}{|c|}{ Crete } & 8336 & 0.027 & 4.32 & 0.976 & 0.795 & 0.98 & 11682 & 1.42 & 62.92 & 1.52 & 0.591 & 1.218 & 167.9 & 98.75 \\
\hline \multirow{4}{*}{ District } & Chania & 2376 & 0.045 & 3.78 & 0.965 & 0.81 & 0.974 & 3144 & 1.34 & 33.08 & 1.53 & 0.595 & 1.232 & 188.4 & 98.95 \\
\hline & Rethymno & 1496 & 0.099 & 4.16 & 0.975 & 0.835 & 0.981 & 2600 & 1.76 & 30.74 & 1.55 & 0.6 & 1.212 & 81.98 & 98.3 \\
\hline & Herakleio & 2641 & 0.075 & 3.93 & 0.951 & 0.743 & 0.956 & 2910 & 1.10 & 30.69 & 1.53 & 0.591 & 1.196 & 245.53 & 98.96 \\
\hline & Lasithi & 1823 & 0.059 & 3.72 & 0.964 & 0.799 & 0.973 & 3231 & 1.8 & 34.24 & 1.49 & 0.581 & 1.223 & 126.35 & 98.49 \\
\hline
\end{tabular}

873

\begin{tabular}{|c|c|c|c|c|c|c|c|c|c|c|c|c|c|c|c|}
\hline \multirow{2}{*}{\multicolumn{2}{|c|}{ (b) }} & \multirow{2}{*}{$\begin{array}{c}\text { Area } \\
\left(\mathbf{k m}^{2}\right)\end{array}$} & \multicolumn{13}{|c|}{ Landscape and patch metrics (Geomorphometric classification) } \\
\hline & & & $P R D$ & SHDI & SIDI & SHEI & SIEI & $N P$ & $P D$ & $L S I$ & SHAPE & CIRCLE & PAFRAC & PROX & COHESION \\
\hline \multicolumn{2}{|c|}{ Crete } & 8336 & 0.01 & 1.972 & 0.849 & 0.948 & 0.971 & 17457 & 2.11 & 64.25 & 1.181 & 0.216 & 1.459 & 859.93 & 98.83 \\
\hline \multirow{4}{*}{ District } & Chania & 2376 & 0.003 & 1.971 & 0.848 & 0.948 & 0.969 & 4691 & 1.98 & 33.53 & 1.17 & 0.2136 & 1.454 & 903.73 & 99.01 \\
\hline & Rethymno & 1496 & 0.006 & 2.007 & 0.858 & 0.965 & 0.981 & 3062 & 2.07 & 26.97 & 1.19 & 0.22 & 1.44 & 357.44 & 98.36 \\
\hline & Herakleio & 2641 & 0.003 & 1.806 & 0.807 & 0.868 & 0.922 & 6047 & 2.29 & 37.07 & 1.183 & 0.2198 & 1.468 & 1010.2 & 98.86 \\
\hline & Lasithi & 1823 & 0.004 & 1.951 & 0.846 & 0.938 & 0.967 & 3755 & 2.08 & 32.18 & 1.19 & 0.2195 & 1.436 & 401.28 & 98.54 \\
\hline
\end{tabular}

874

\begin{tabular}{|c|c|c|c|c|c|c|c|c|c|c|c|c|c|c|c|}
\hline \multirow{2}{*}{\multicolumn{2}{|c|}{ (c) }} & \multirow{2}{*}{$\begin{array}{c}\text { Area } \\
\left(\mathbf{k m}^{2}\right)\end{array}$} & \multicolumn{13}{|c|}{ Landscape and patch metrics (Geological classification) } \\
\hline & & & $P R D$ & SHDI & SIDI & SHEI & SIEI & $N P$ & $P D$ & $L S I$ & SHAPE & CIRCLE & PAFRAC & PROX & COHESION \\
\hline \multicolumn{2}{|c|}{ Crete } & 8336 & 0.001 & 2.021 & 0.834 & 0.813 & 0.909 & 3829 & 0.459 & 36.83 & 1.62 & 0.61 & 1.26 & 1657.97 & 99.54 \\
\hline \multirow{4}{*}{ District } & Chania & 2376 & 0.004 & 1.811 & 0.814 & 0.786 & 0.905 & 1141 & 0.479 & 19.7 & 1.63 & 0.628 & 1.285 & 2005.85 & 99.62 \\
\hline & Rethymno & 1496 & 0.008 & 1.996 & 0.833 & 0.803 & 0.909 & 722 & 0.488 & 18.93 & 1.77 & 0.65 & 1.287 & 710.07 & 99.3 \\
\hline & Herakleio & 2641 & 0.004 & 1.870 & 0.779 & 0.78 & 0.857 & 689 & 0.26 & 16.27 & 1.67 & 0.62 & 1.253 & 2056.1 & 99.65 \\
\hline & Lasithi & 1823 & 0.005 & 1.725 & 0.787 & 0.749 & 0.875 & 1407 & 0.77 & 21.71 & 1.5 & 0.58 & 1.251 & 1338.75 & 99.47 \\
\hline
\end{tabular}

875

876 Table 6. a) Landscape and patch metrics for Crete and the individual districts of Crete, based on the geodiversity map of the island; b)

877 landscape and patch metrics for Crete and the individual districts of Crete, based on the geomorphometric classification of the island;

878 c) landscape and patch metrics for Crete and the individual districts of Crete, based on the geological classification of the island. 